\title{
The Distribution of MVT-Related Metals in Ground Water of the Ozark Plateaus Region of the United States
}

By Lopaka Lee and Martin B. Goldhaber

U.S. Geological Survey Open File Report 01-171

U.S. Department of the Interior

U.S. Geological Survey 


\title{
U.S. Department of the Interior
}

\author{
Gale A. Norton, Secretary
}

\section{U.S. Geological Survey}

Charles G. Groat, Director

For sale by U.S. Geological Survey, Information Services

Box 25286, Denver Federal Center

Denver, CO 80225

For more information about the USGS and its products:

Telephone: 1-888-ASK-USGS

World Wide Web: http://www.usgs.gov/

This publication is also available online at:

http://geology.cr.usgs.gov/

Any use of trade, product, or firm names in this publication

is for descriptive purposes only and does not

imply endorsement by the U.S. Government 


\section{Contents}

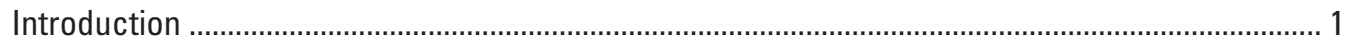

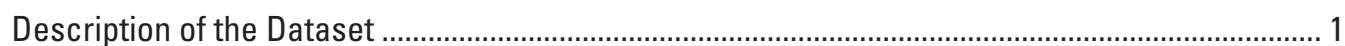

Maps of the Concentrations of Dissolved Metals in Ozark Region Ground Water........................... 2

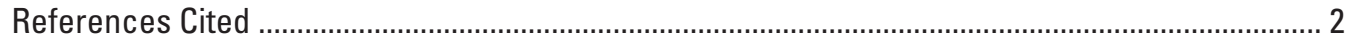

Appendix A: Tabular Listing of Chemical Analyses of Ground Water Samples ........................... 13

\section{Figures}

1. Locations of ground water sampling sites .................................................................... 3

2. Distribution of dissolved arsenic in ground water samples of the Ozark region............... 4

3. Distribution of dissolved cadmium in ground water samples of the Ozark region ............ 5

4. Distribution of dissolved cobalt in ground water samples of the Ozark region ................. 6

5. Distribution of dissolved chromium in ground water samples of the Ozark region .......... 7

6. Distribution of dissolved copper in ground water samples of the Ozark region............... 8

7. Distribution of dissolved nickel in ground water samples of the Ozark region.................. 9

8. Distribution of dissolved lead in ground water samples of the Ozark region.................. 10

9. Distribution of dissolved zinc in ground water samples of the Ozark region ................... 11

10. Geologic sources of ground water samples that contain at least one trace element that is elevated in comparison to typically observed concentrations............................. 12

A1. Index for map coverages in figures A2 through A5 ....................................................... 14

A2. Index numbers for ground water sampling sites in the northwest Ozark region ........... 15

A3. Index numbers for ground water sampling sites in the southwest Ozark region ............ 16

A4. Index numbers for ground water sampling sites in the south-central Ozark region ...... 17

A5. Index numbers for ground water sampling sites in the eastern Ozark region ................ 18

\section{Tables}

1. Statistical distribution of ground water samples by formation and aquifer unit .............. 2

A1. Tabular listing of ground water analyses .......................................................................... 19 


\title{
The Distribution of MVT-Related Metals in Ground Water of the Ozark Plateaus Region of the United States
}

\author{
By Lopaka Lee and Martin B. Goldhaber
}

\section{Introduction}

This report is a compilation of figures and tables that show the spatial and statistical distribution of dissolved elemental concentrations of $\mathrm{As}, \mathrm{Ba}, \mathrm{Cd}, \mathrm{Co}, \mathrm{Cu}, \mathrm{Cr}, \mathrm{Mo}, \mathrm{Ni}, \mathrm{Pb}$, and $\mathrm{Zn}$, in ground water from the Ozark Plateaus region of the United States.

This product is part of a USGS project that is focused on characterizing the effects of Mississippi Valley-type (MVT) mineralization on the background ground water chemistry of the Ozark Plateaus region of the United States (Lee, 2000). The first phase of this parent study involved the investigation of spatial and statistical relationships between MVT-related metals in rocks and groundwater. The figures and tables of this report are a product of this study phase and are centered on characterizing, on a regional level, the spatial and statistical distribution of MVT-related metals in aquifer rocks. A companion report that shows the spatial and statistical distribution of MVT-related metals in acid-insoluble residues of borehole rocks from the Ozark region has been published as a USGS open-file report under the title: The distribution of MVT-related metals in acid-insoluble residues of Paleozoic rocks in the Ozark Plateaus region of the United States (Lee and Goldhaber, 2001).

A minimal amount of scientific interpretations are provided within the text. A detailed interpretation of this data, as it relates to the effects of MVT mineralization on the naturalbackground ground water chemistry of the Ozark region, is currently available in Lee (2000).

\section{Description of the Dataset}

The figures and tables of this report are based on a database of 400 ground-water samples from 380 different locations distributed throughout the Ozark region (Figure 1). The entire ground-water dataset, along with instructions on how to obtain digital copies of records, is listed in Appendix A.

All ground-water samples used within this report were generated during USGS Water-Resources Division (USGSWRD) programs. Ground-water samples are from both springs and wells. A majority of these water samples are associated with the USGS National Water Quality Assessment (NAWQA) Program - Ozark Plateaus Study Unit (Freiwald, 1991; Peterson, Adamski, and others, 1998). A smaller set of the USGS water data is from water-quality monitoring programs implemented by the USGS-WRD, but not directly associated with the NAWQA program. These samples were obtained by the same office and personnel executing the Ozark NAWQA study and were obtained and analyzed in accordance with standard USGS protocol (see USGS Technical Water Resources Investigations (TWRI) manuals available at ( $\underline{\mathrm{http}: / /}$ oregon.usgs.gov/pubs dir/twri-list.html ).

All ground-water samples used in this report are full determinations of major elements and field parameters.

Data records for ground-water samples contain information on the principal water-bearing geologic formations of springs and wells, and also well construction information where relevant. Table 1 summarizes the statistical distribution of water samples by water-yielding formation (or geologic unit). The total percentage of groundwater samples representative of the individual aquifer units of the Ozark Aquifer System are: $36 \%$ from the Springfield Plateau aquifer unit, $64 \%$ from the Ozark aquifer unit, and 0\% from the St. Francois aquifer unit. Groundwater samples from the St. Francois aquifer unit were not obtained for use in this report. This aquifer is of minor importance as a drinking water source in the Ozarks (Imes and Emmett, 1994).

Trace elements were determined in 200 ground-water samples (Table 1). The total percentage of groundwater samples with trace element data representative of individual aquifer units of the Ozark aquifer system are: $20 \%$ from the Springfield Plateau aquifer unit, and $80 \%$ from the Ozark aquifer unit. The lower detection limit for almost all trace metal analyses within the dataset is $1 \mathrm{ug} / \mathrm{L}$. However, for some analyses, detection limits are as high as $6 \mathrm{ug} / \mathrm{L}$. For mapping and plotting purposes, all concentrations of trace elements reported at the lower limits of detection were set to one-half of the reported detection limit. 
Table 1. Statistical distribution of ground-water samples by geologic formation and aquifer unit $\begin{array}{ccc}\text { Hydrologic Unit } & \begin{array}{c}\text { Groundwater Analyses } \\ \text { (with major ions) }\end{array} & \begin{array}{c}\text { Groundwater Analyses } \\ \text { (with trace elements) }\end{array}\end{array}$

\begin{tabular}{lcc}
\hline Western Int. Plains confining & 0 & 0 \\
Springfield Plateau aquifer & 144 & 40 \\
Ozark confining & 0 & 0 \\
Ozark aquifer & 256 & 160 \\
St. Francois confining & 0 & 0 \\
St. Francois aquifer & 0 & 0 \\
Basement confining & 0 & 0 \\
\hline \multicolumn{1}{c}{ TOTAL } & 400 & 200
\end{tabular}

\section{Maps of the Concentrations of Dissolved Metals in Ozark Region Ground Water}

Figures 2 through 9 show the distribution of dissolved MVT metals in groundwater samples. Over most of the Ozark region, the observed concentrations of MVT-related metals are typically below $100 \mathrm{ug} / \mathrm{L}$ for $\mathrm{Zn}$ and below $1-5 \mathrm{ug} / \mathrm{L}$ for all other MVT metals. However, dissolved concentrations in excess of these limits consistently occur in the southwestern portion of the Ozark region. In this area, concentrations of MVT metals in groundwater are elevated with respect to regional concentrations. Dissolved $\mathrm{Zn}$ in this area occurs in concentrations up to $2000 \mathrm{ug} / \mathrm{L}$ (Figure 9). Dissolved As, Cd, Co, and Cr, exceed 1 ug/L (Figures 2 through 5). The highest concentrations of dissolved metals occur in a northwest-southeast striking trend that contains the Northern Arkansas mining district. This overall trend is coincident with the Chesapeake Tectonic Zone.

Figure 10 shows the geologic source of ground-water samples that contain at least one trace-metal that is elevated with regard to the typically observed concentrations. Elevated dissolved-metal concentrations in northern Arkansas are predominately associated with groundwater from the Everton Formation and Jefferson City-Cotter Dolomites. Other water samples in northern Arkansas with elevated dissolved metal concentrations are associated with wells producing from multiple formations in the upper Ozark aquifer unit. Figure 10 also shows some correlation with elevated metals and structural features such as fault traces and tectonic-zone trends. Elevated metals are observed in the Boone Formation, Jefferson CityCotter Dolomite and Everton Formation, the Roubidoux-Gasconade Dolomites, and to a limited extent, the EminencePotosi Dolomites.

\section{References Cited}

Freiwald, D.A., 1991, National Water-Quality Assessment Program Ozark Plateaus: U.S. Geological Survey Open File Report 91-162, 2 p.

Imes, J.L., and Emmett, L.F., 1994, Geohydrology of the Ozark Plateaus aquifer system in parts of Missouri, Arkansas, Oklahoma, and Kansas: U.S. Geological Survey Professional Paper 1414-D, 127 p.

Lee, L., and Goldhaber, M.B., 2001, The distribution of MVT-related metals in acid insoluble residues of Paleozoic rocks in the Ozark plateaus region of the United States: U.S. Geological Survey Open File Report 01-0042 ( http://geology.cr.usgs.gov/pub/open-filereports/ofr-01-0042 ), $35 \mathrm{p}$.

Lee, R.C.L., 2000, The effect of Mississippi Valley-type mineralization on the natural background chemistry of groundwater in the Ozark Plateaus region of the United States: unpub. Master's thesis, Colorado School of Mines, Golden, C0, 210 p.

Peterson, J.C., Adamski, J.C., Bell, R.W., Davis, J.V., Femmer, S.R., Freiwald, D.A., and Joseph, R.L., 1998, Water-quality assessment in the Ozark Plateaus, Arkansas, Kansas, Missouri, and Oklahoma, 1992-1995: U.S. Geological Survey Circular 1158, 112 p. 


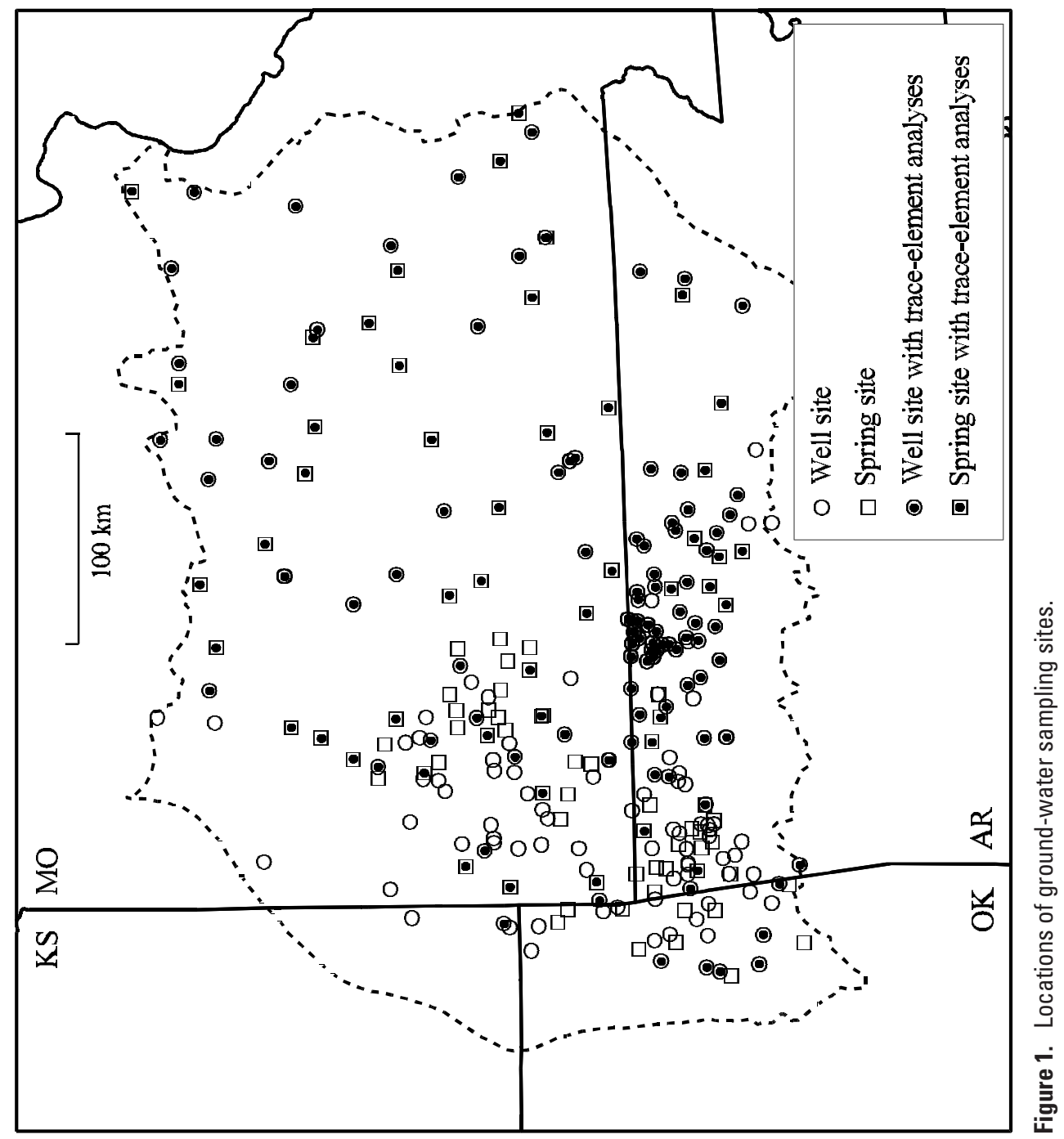




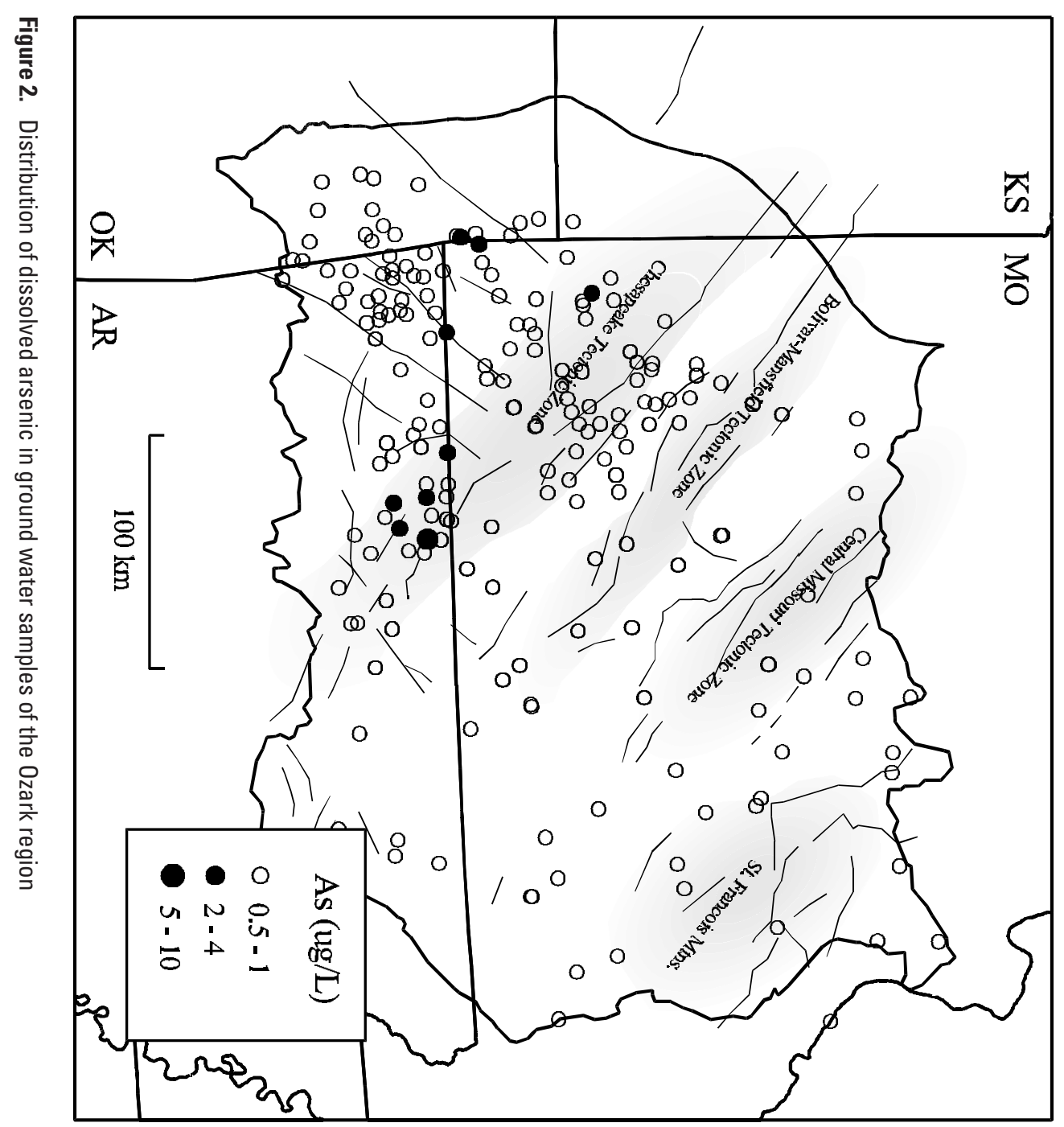




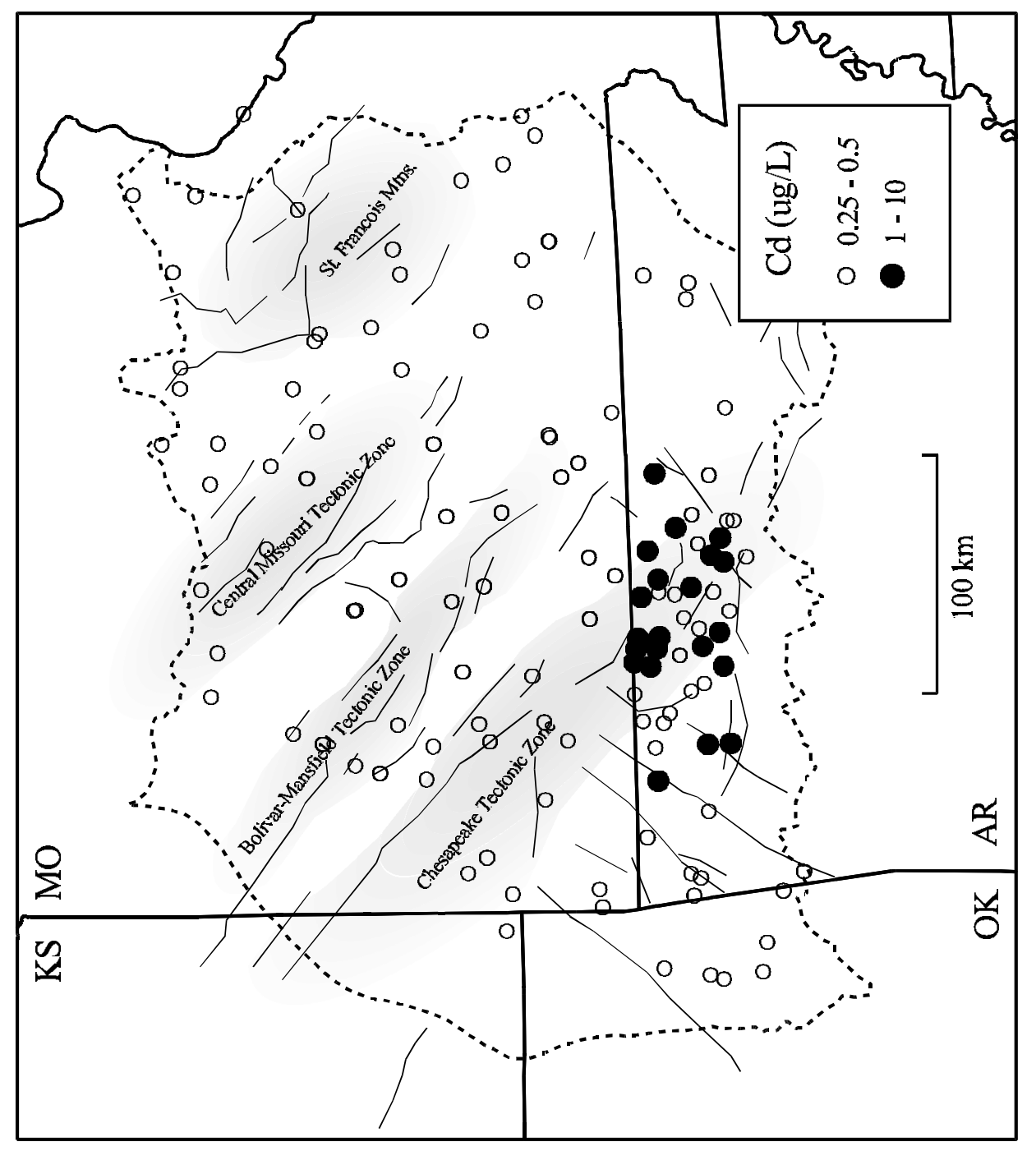

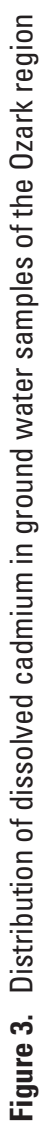




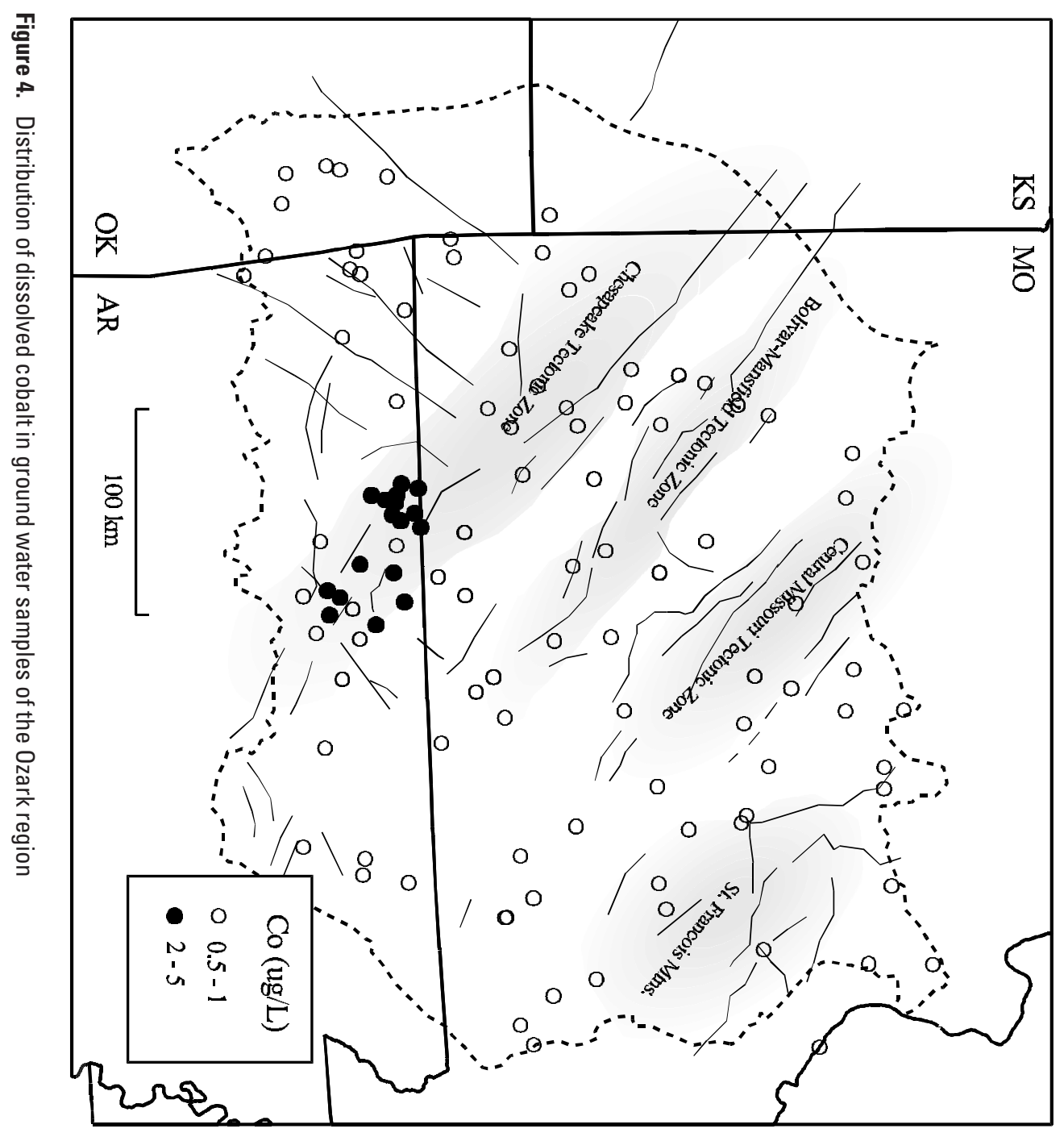




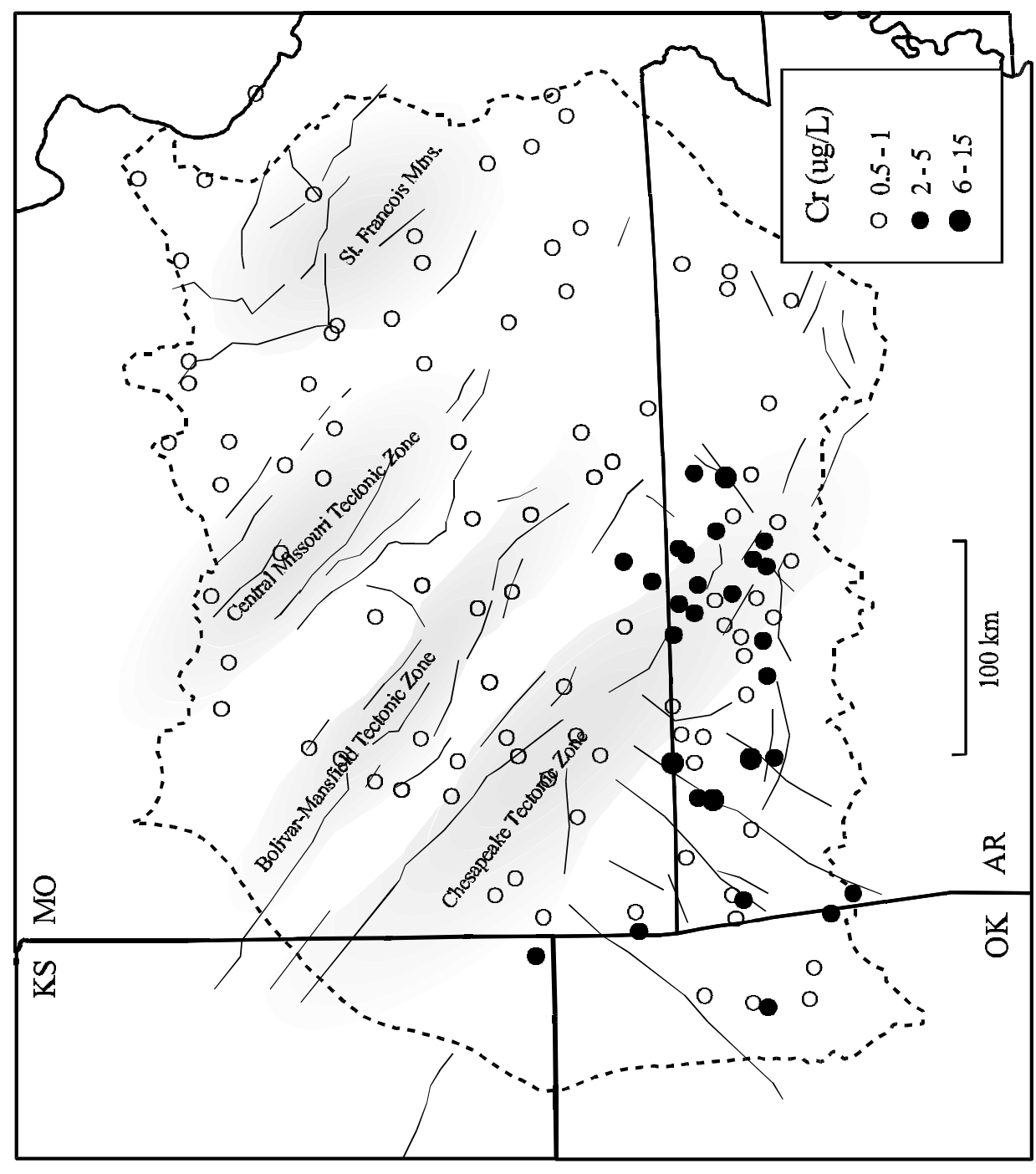

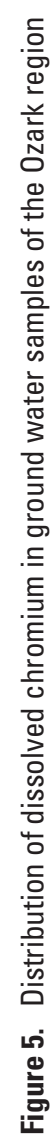




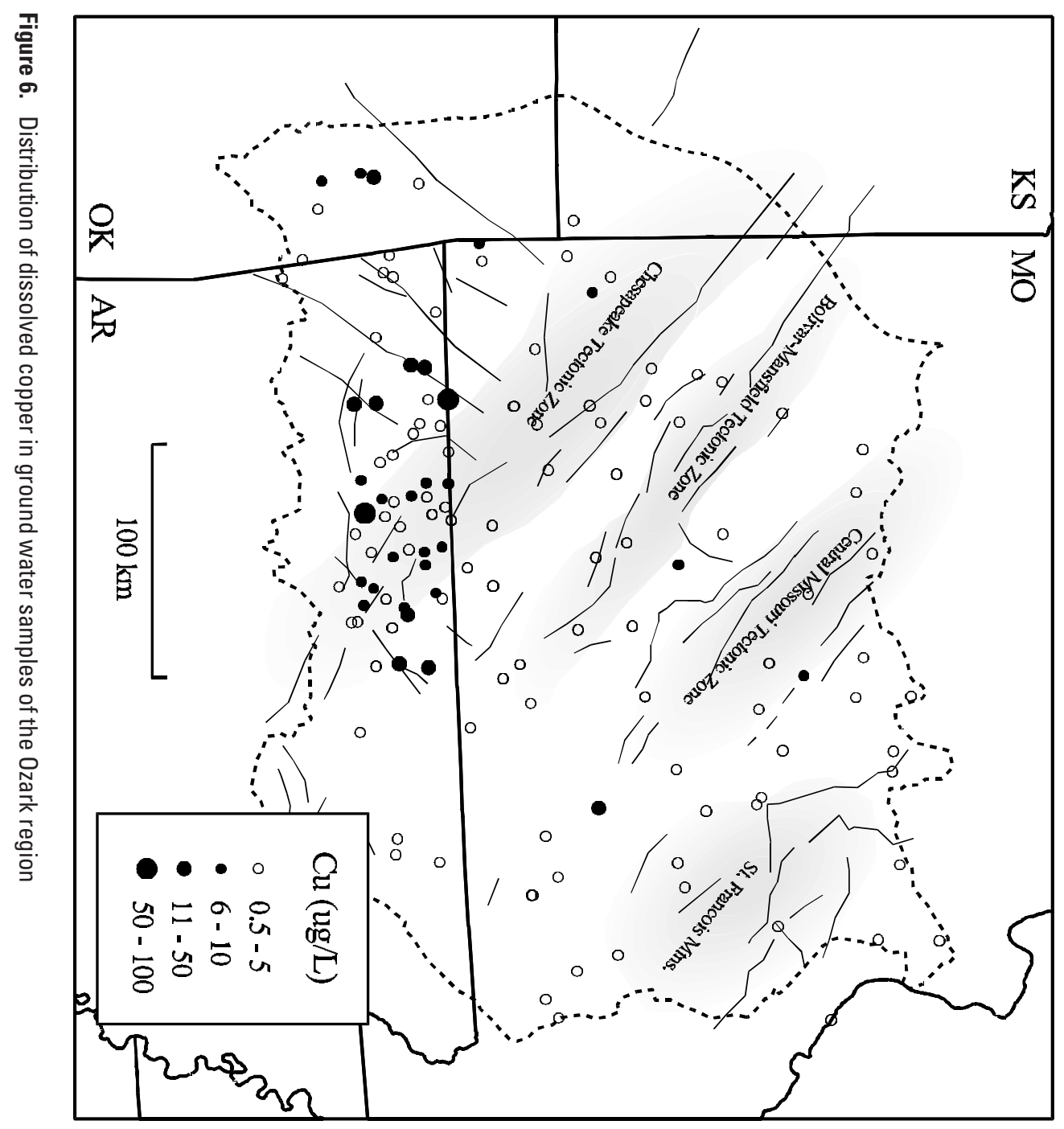




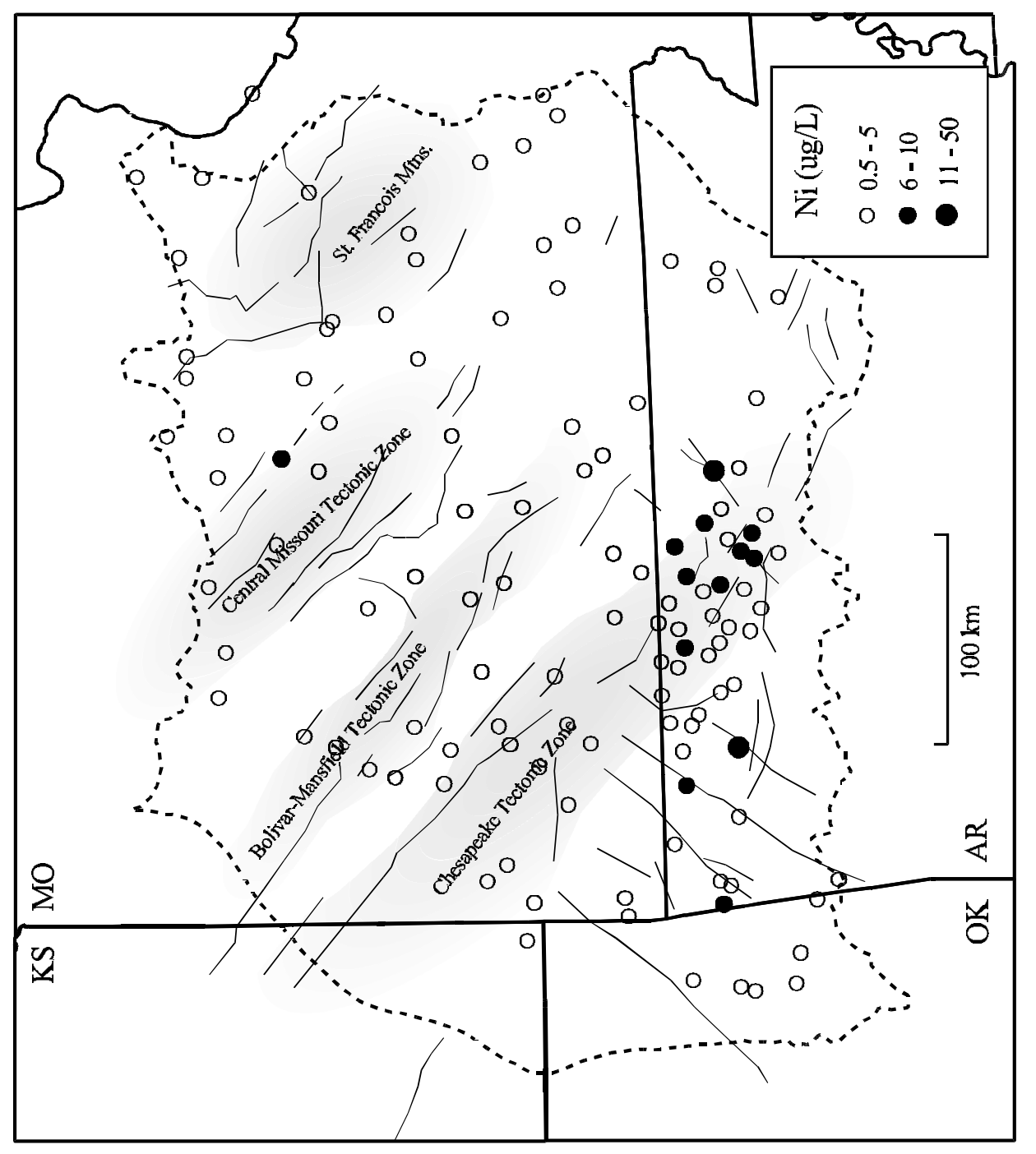

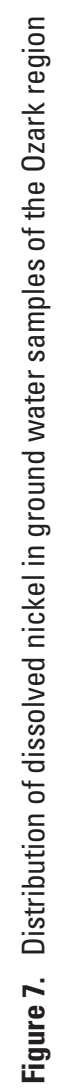




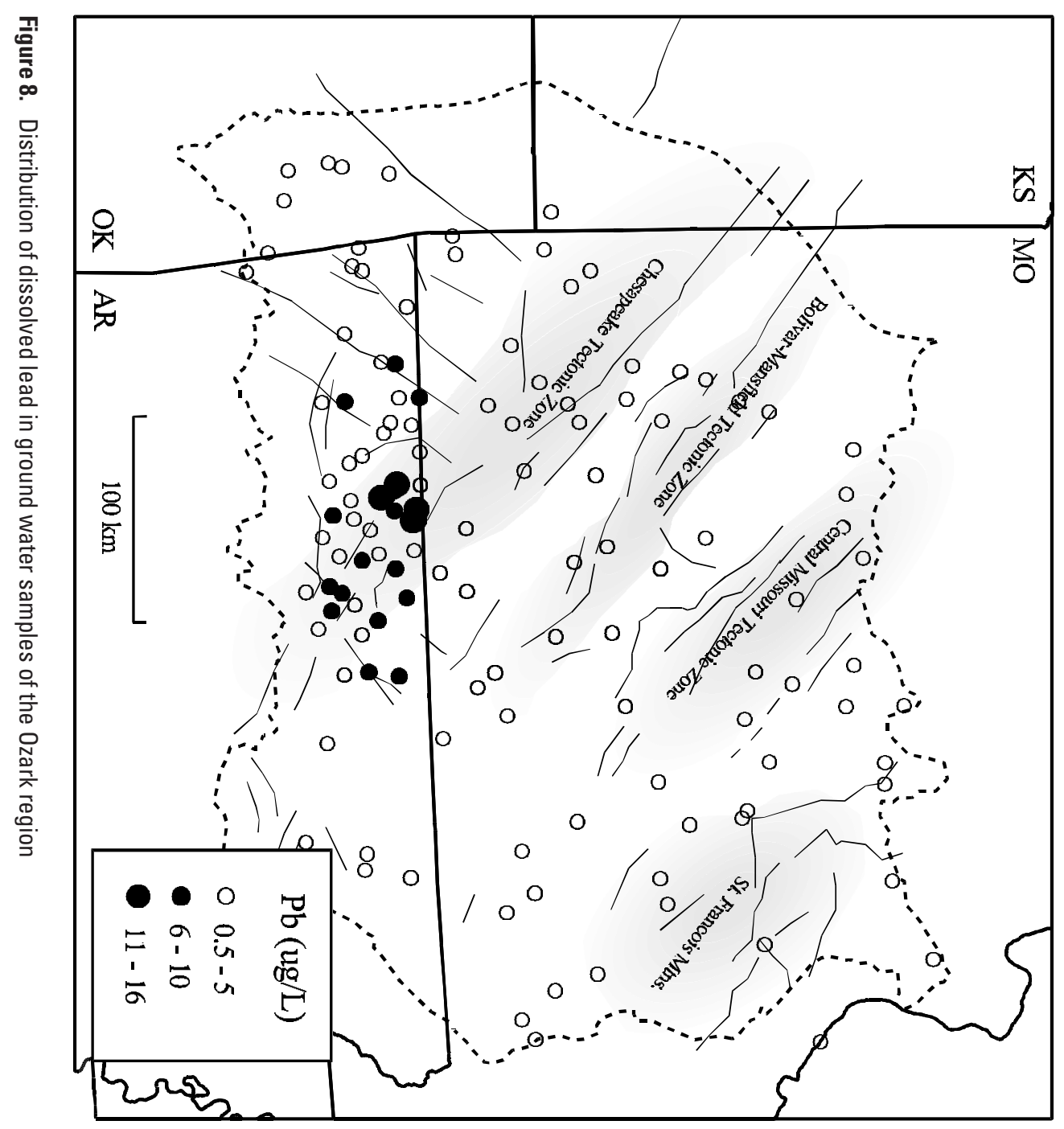




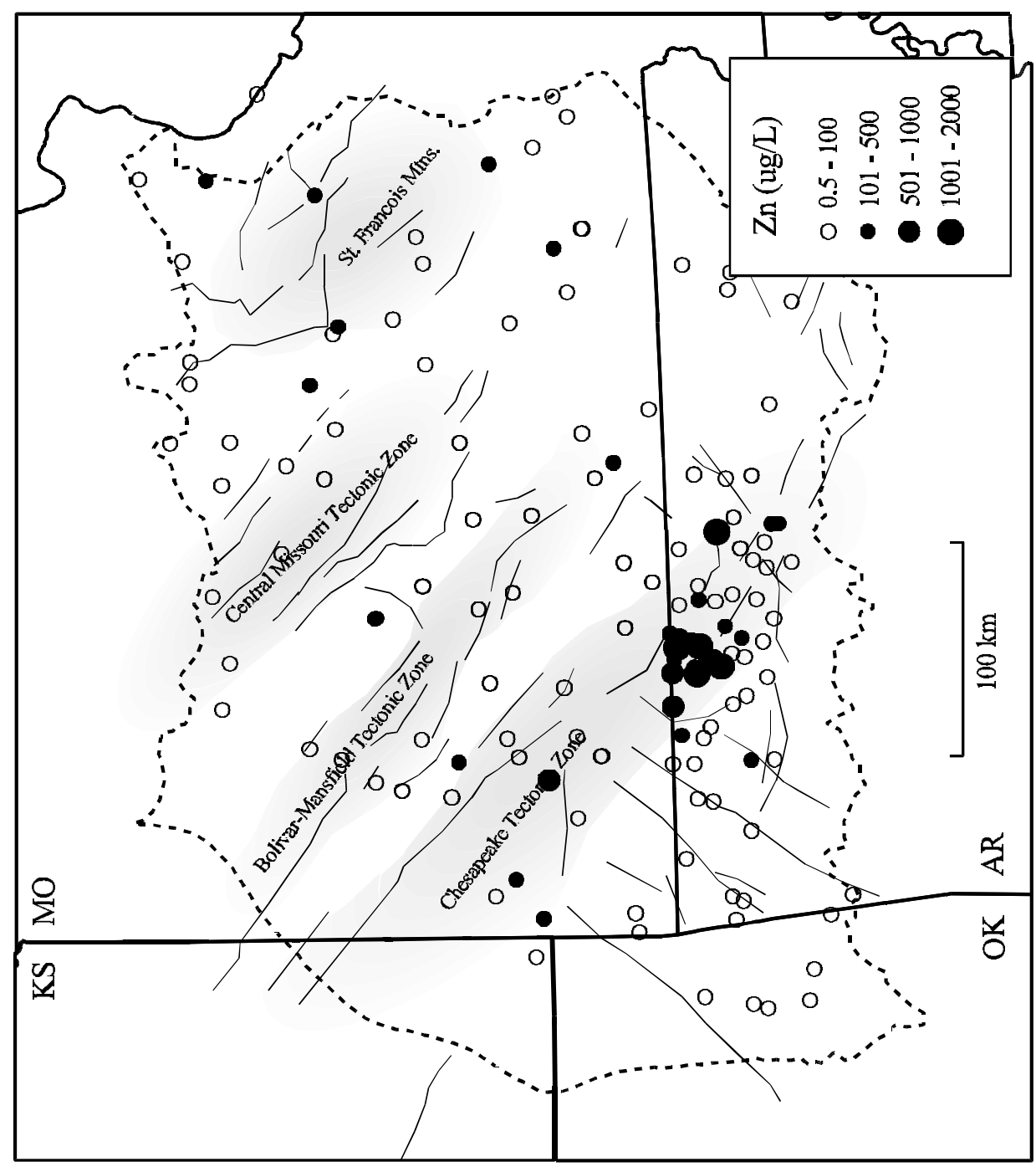

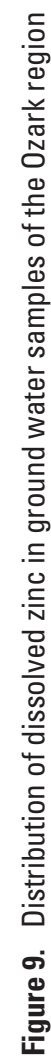




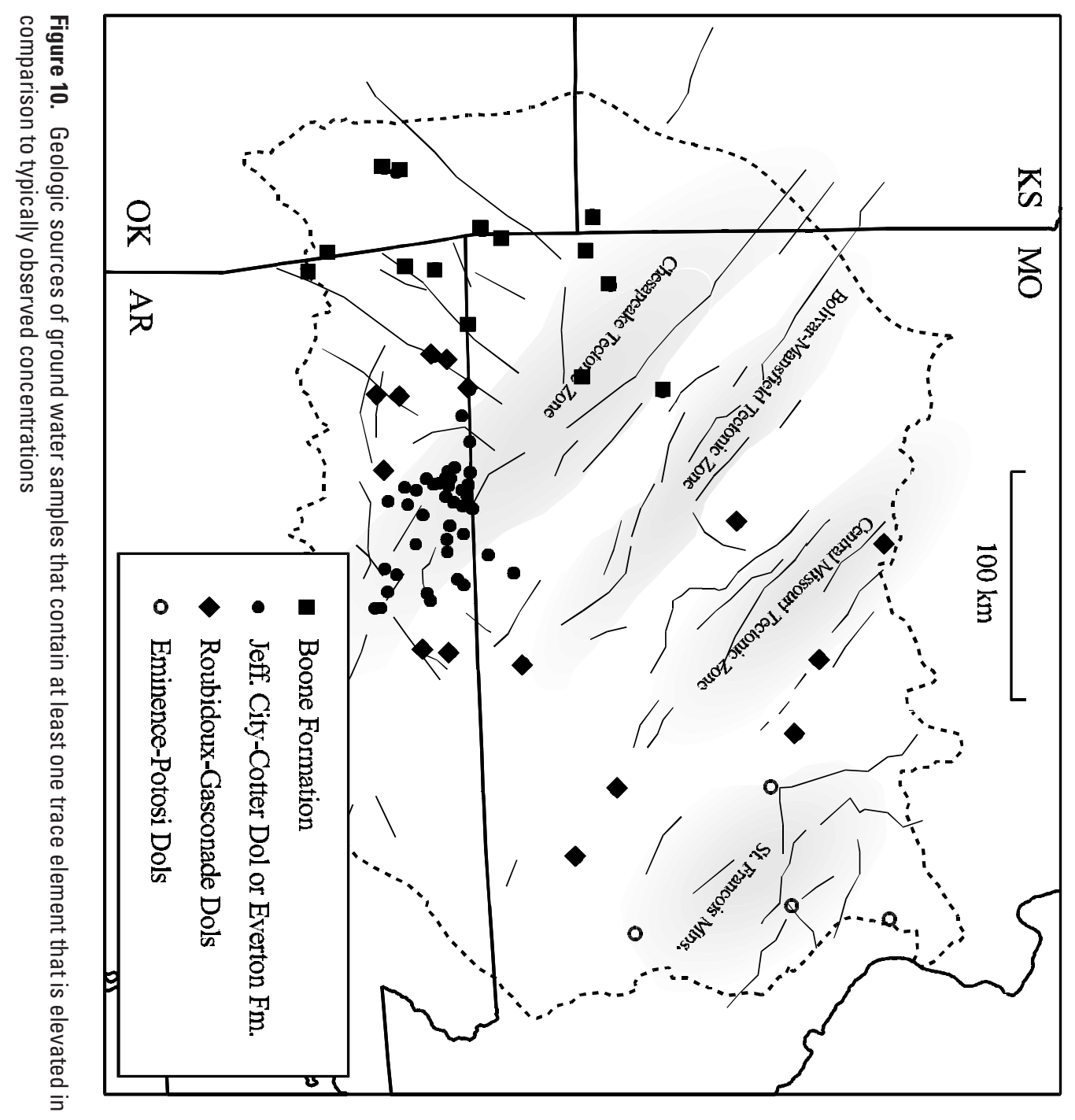




\section{Appendix A: Tabular Listing of Chemical Analyses of Ground Water Samples}

Table A1 lists the dataset used to generate the figures of this report. The listed data records do not contain all of the fields that are available within the USGS Watstore database for each record. Other analyses, not used in this study, may be available at individual sites. Digital copies of this dataset, that contain all available analyses and sample information, may be obtained on-line at http://water.usgs.gov/owq/data.html

Figures A1-A5 are provided as a means to identify individual sites and records. Data for individual sampling sites are obtained by using these figures, and their index numbers, to identify station ID numbers. The listed station ID numbers in table A1 are used to identify sites within the USGS Watstore database. 


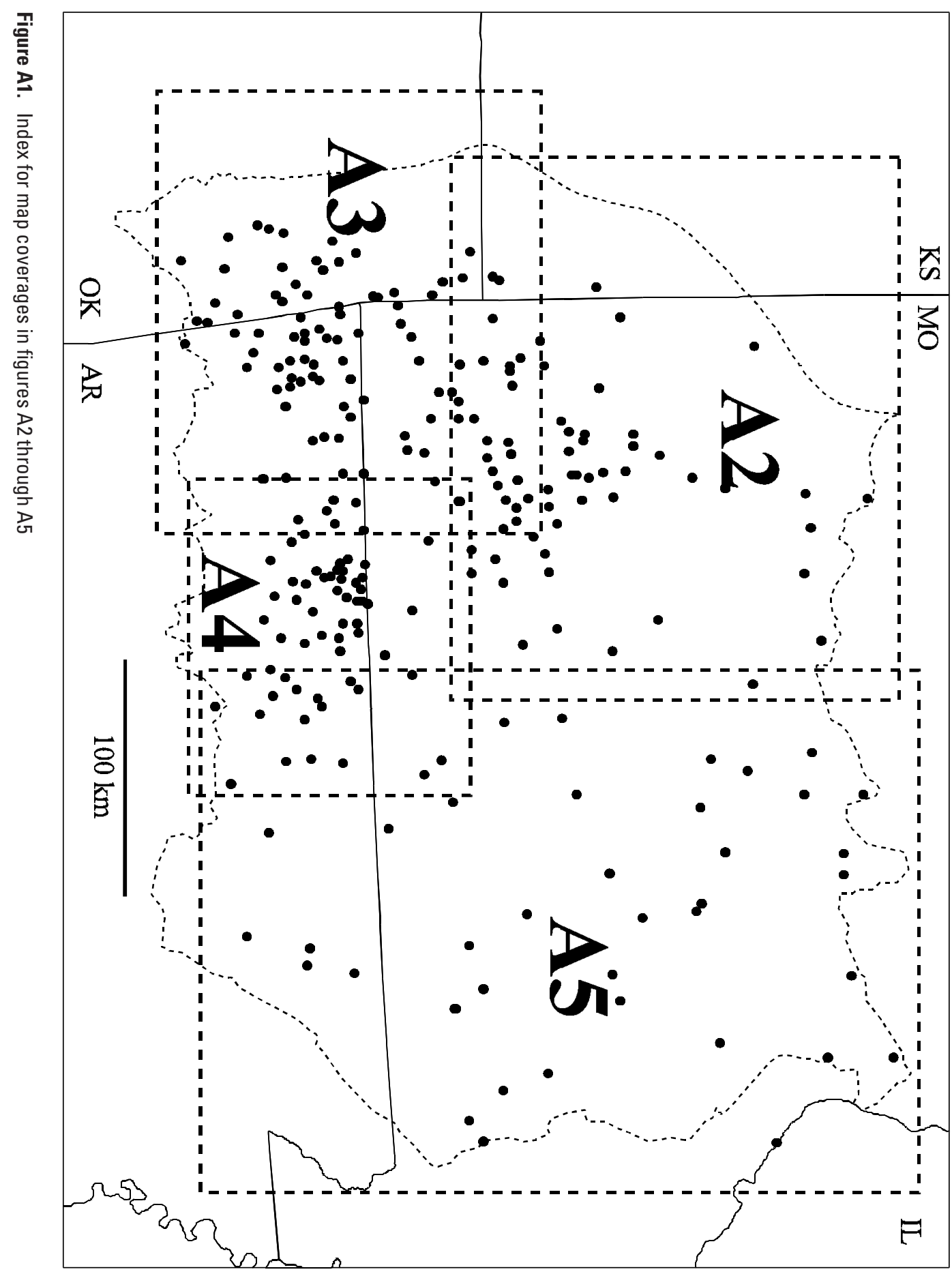




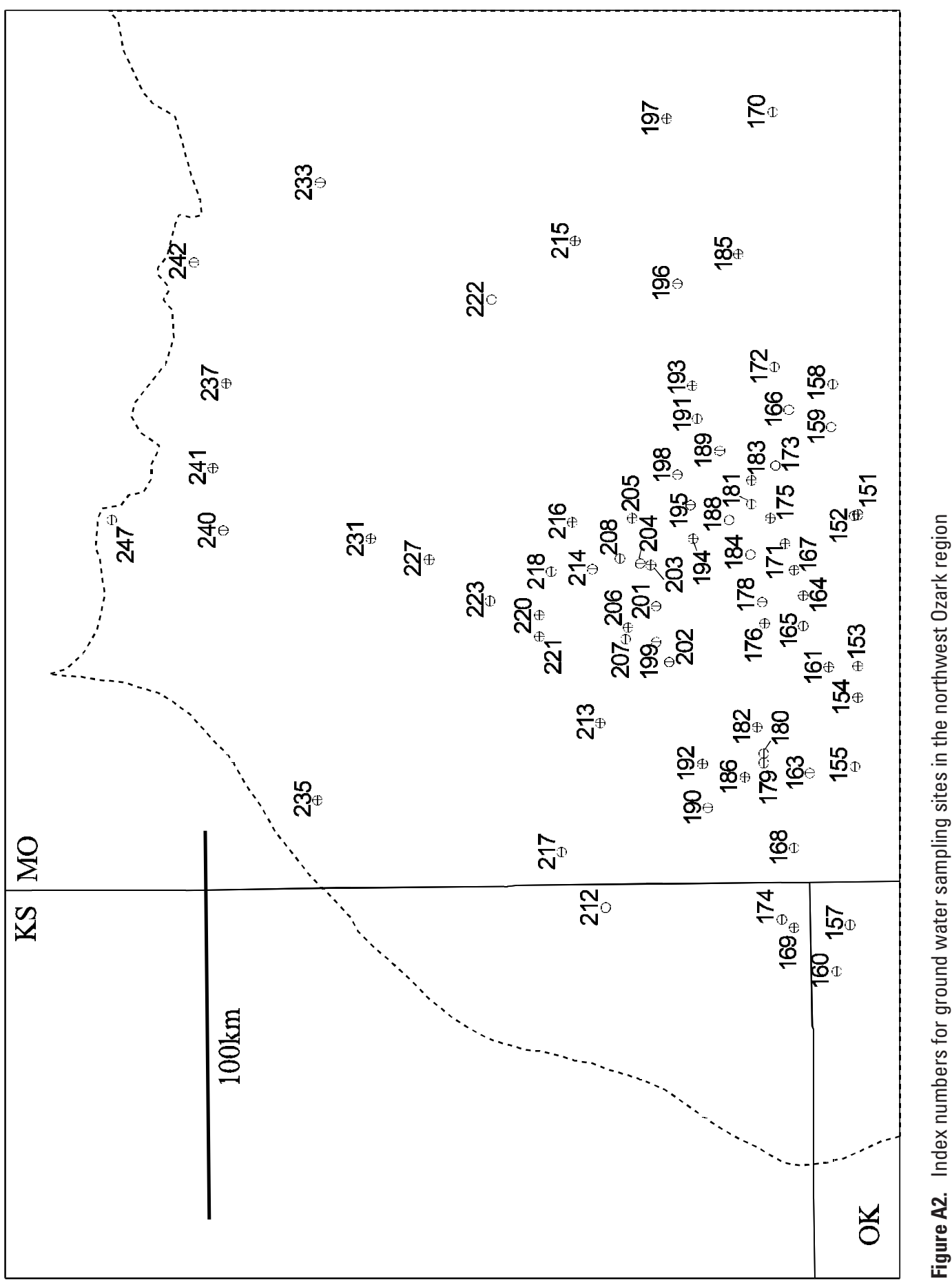




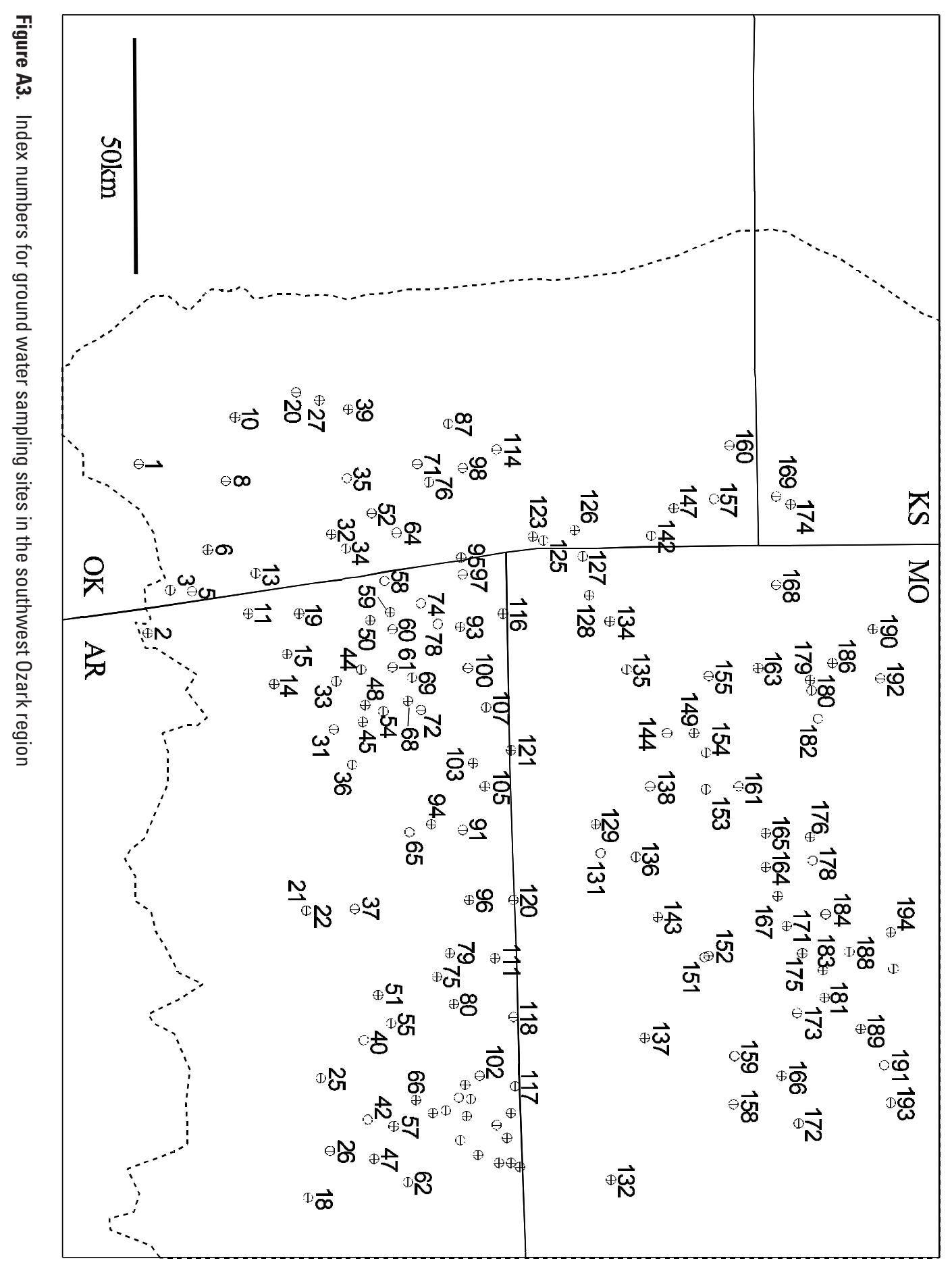




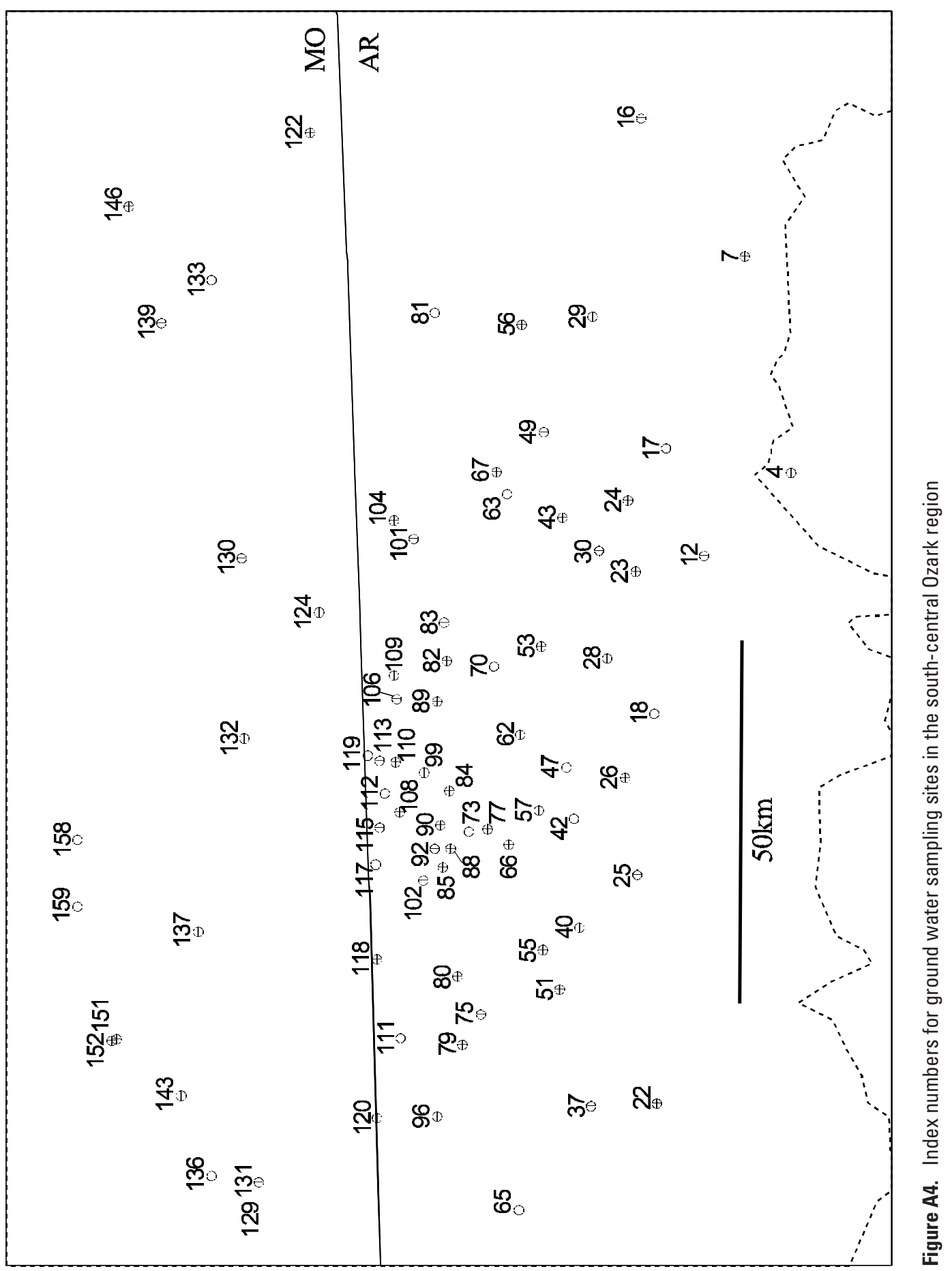




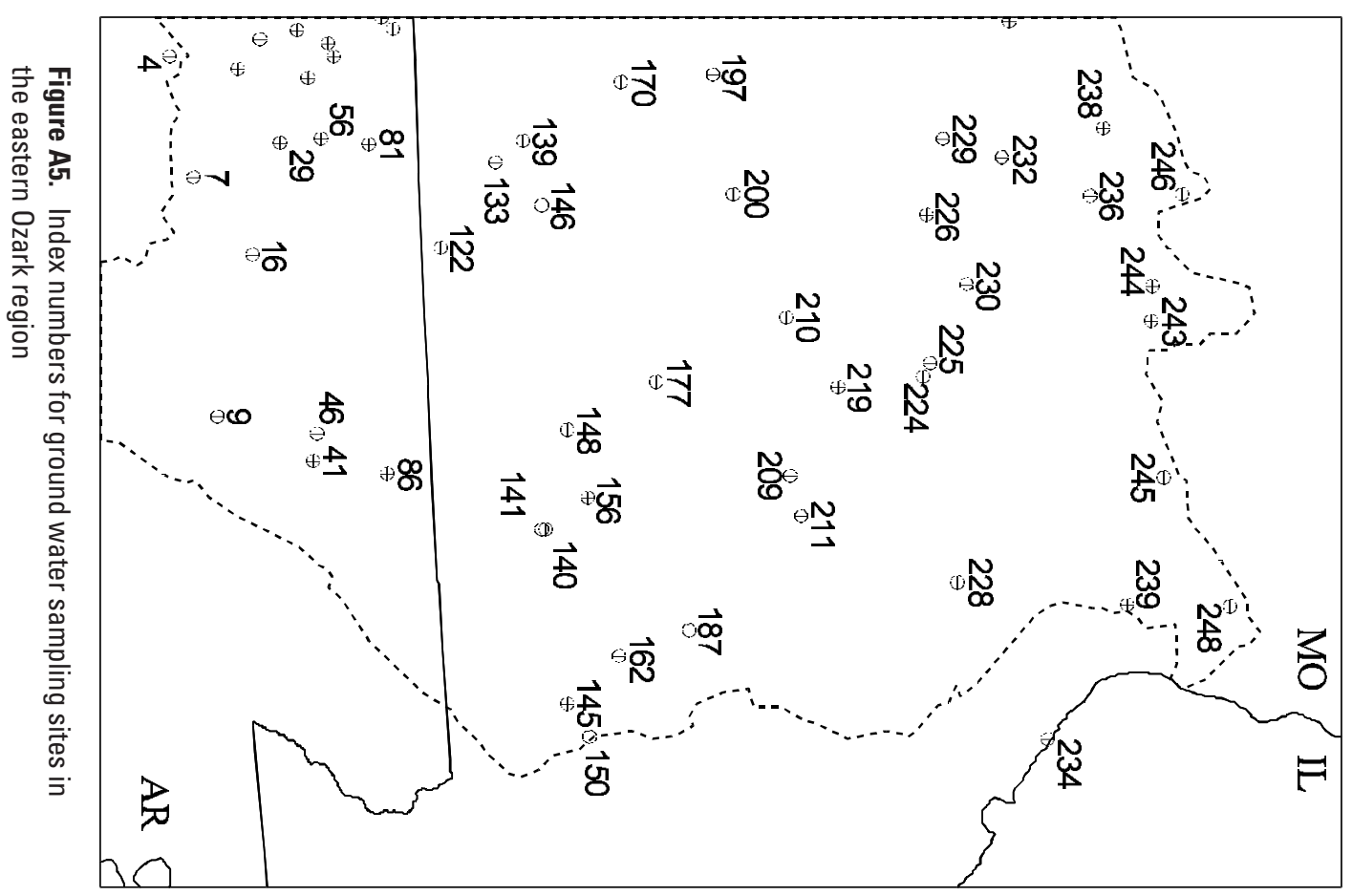




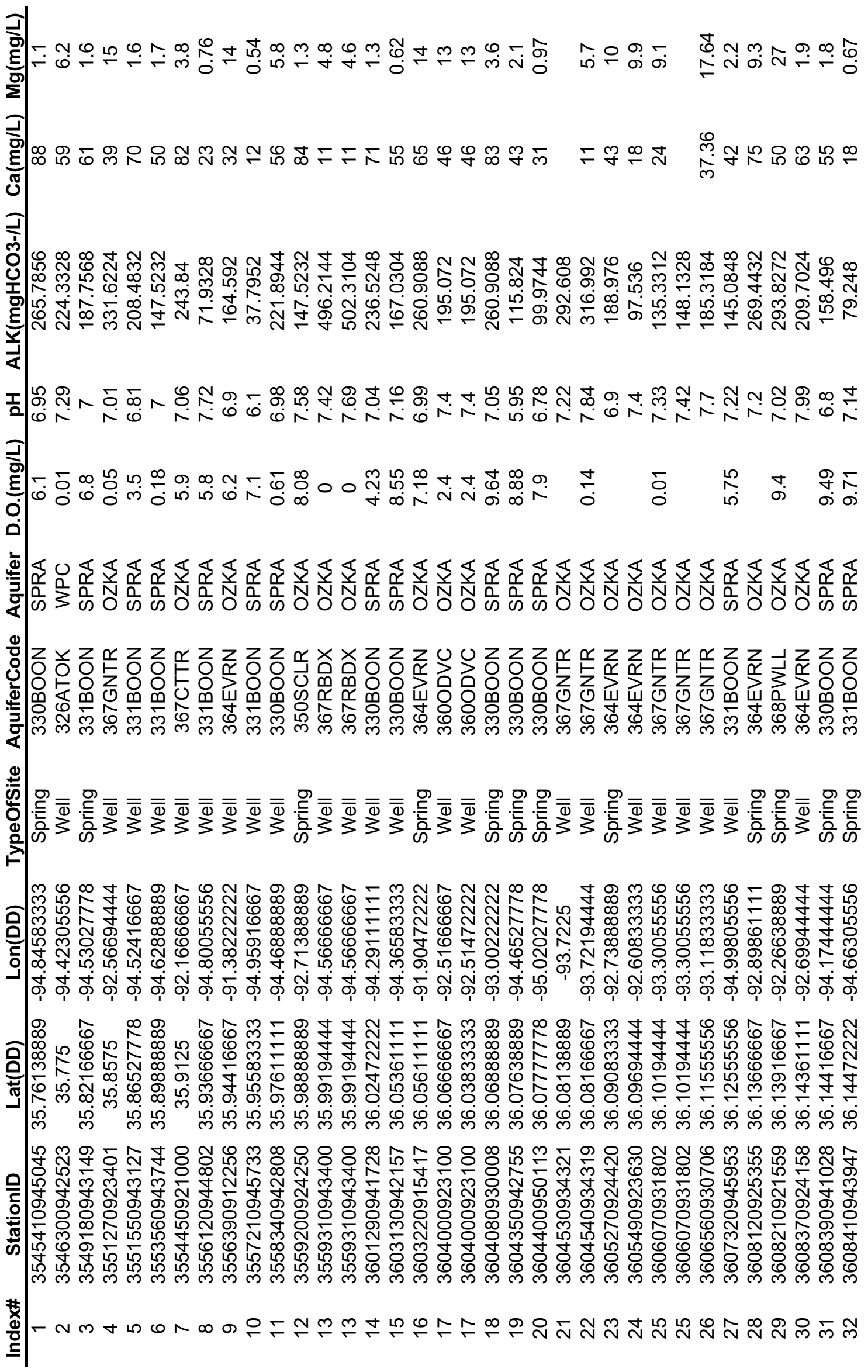




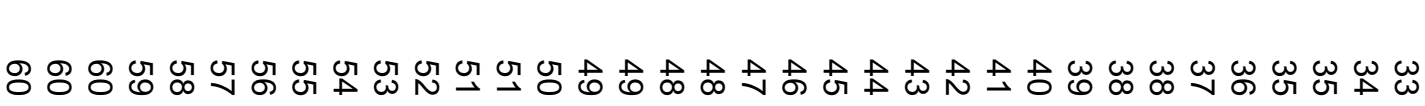
బ

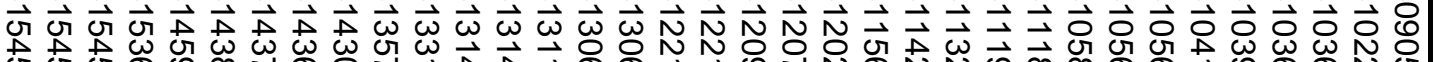

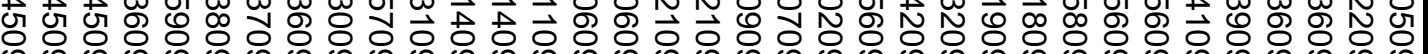

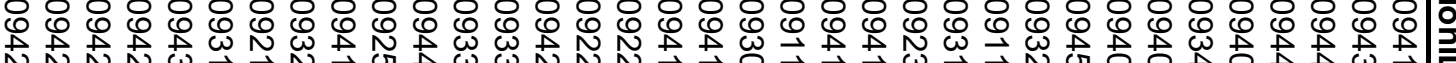

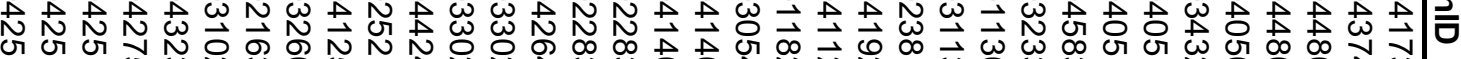

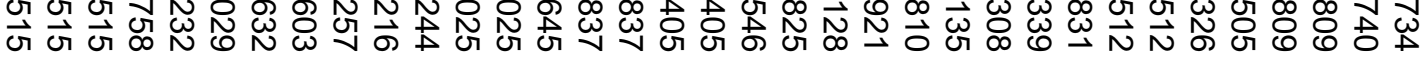

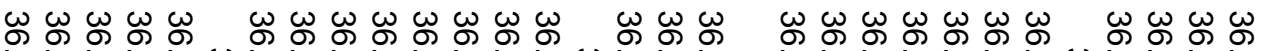

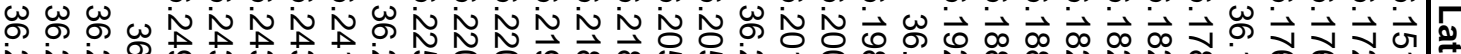

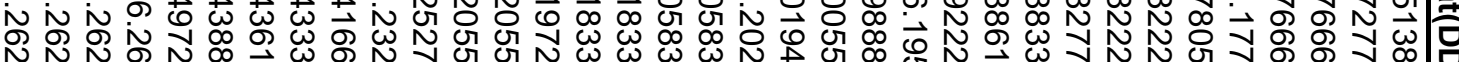

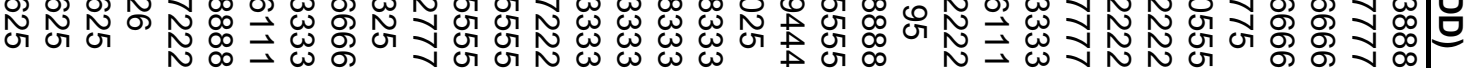
N

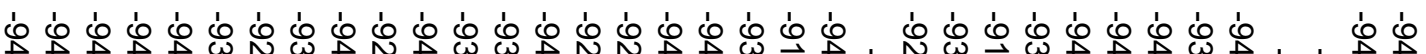

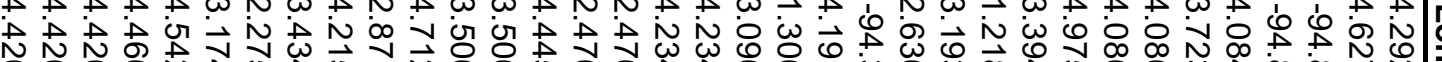

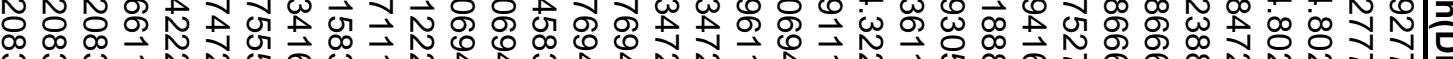

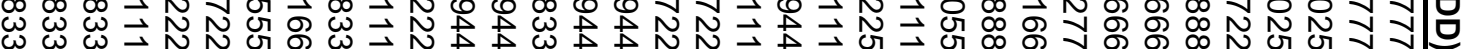

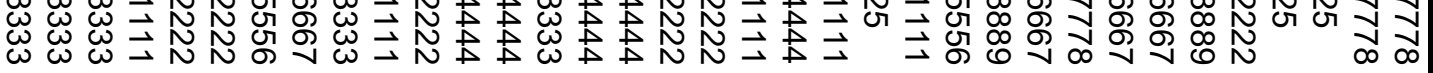

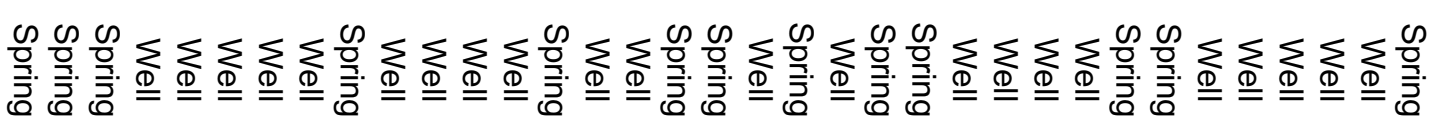

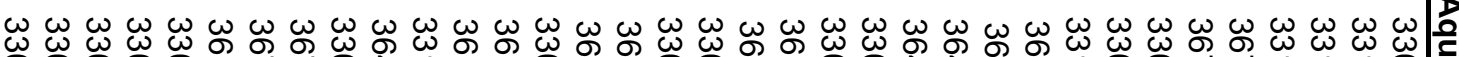

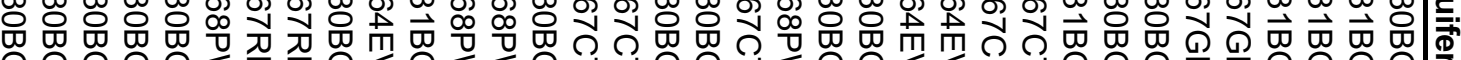

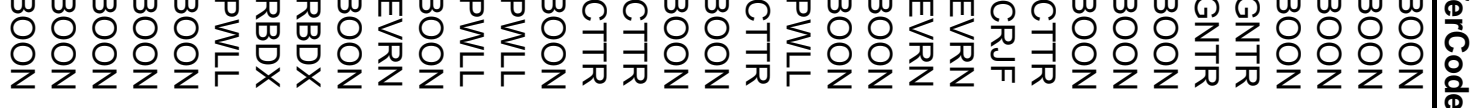

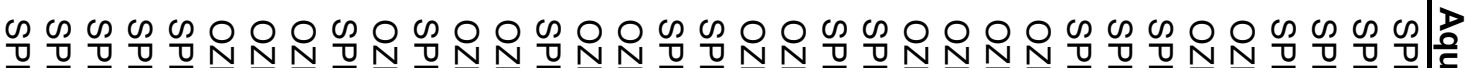

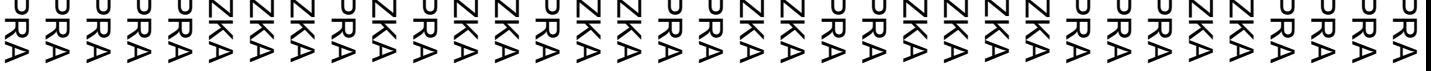

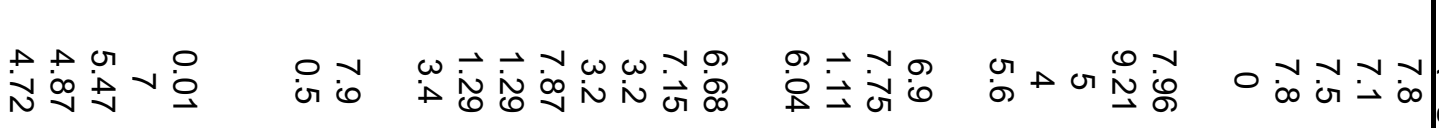

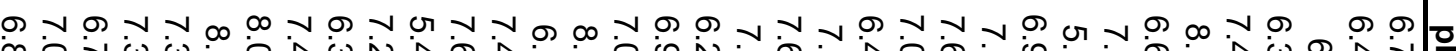

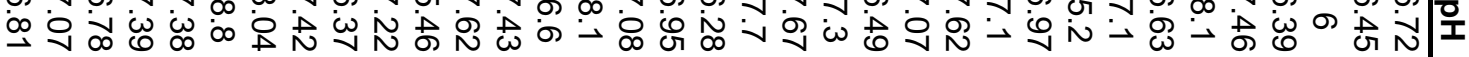

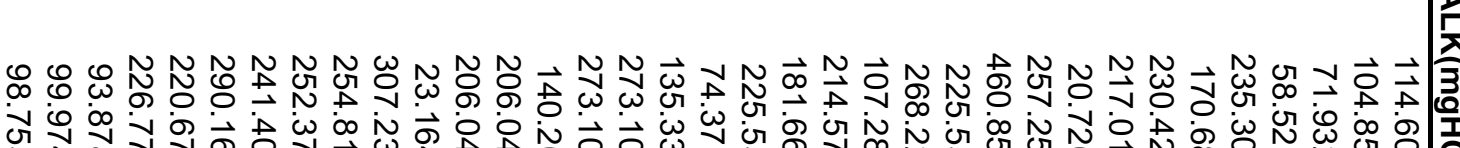
等

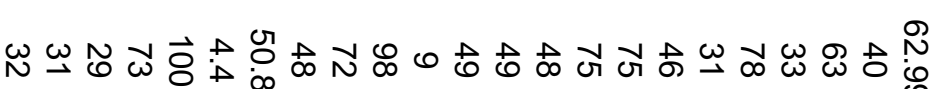

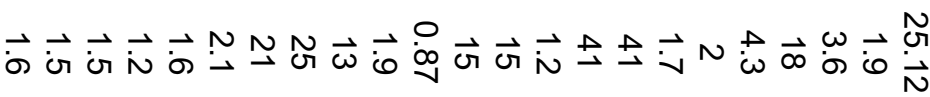

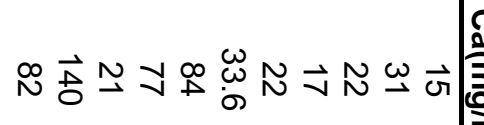

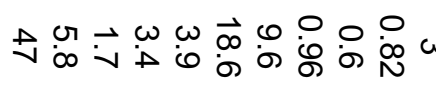




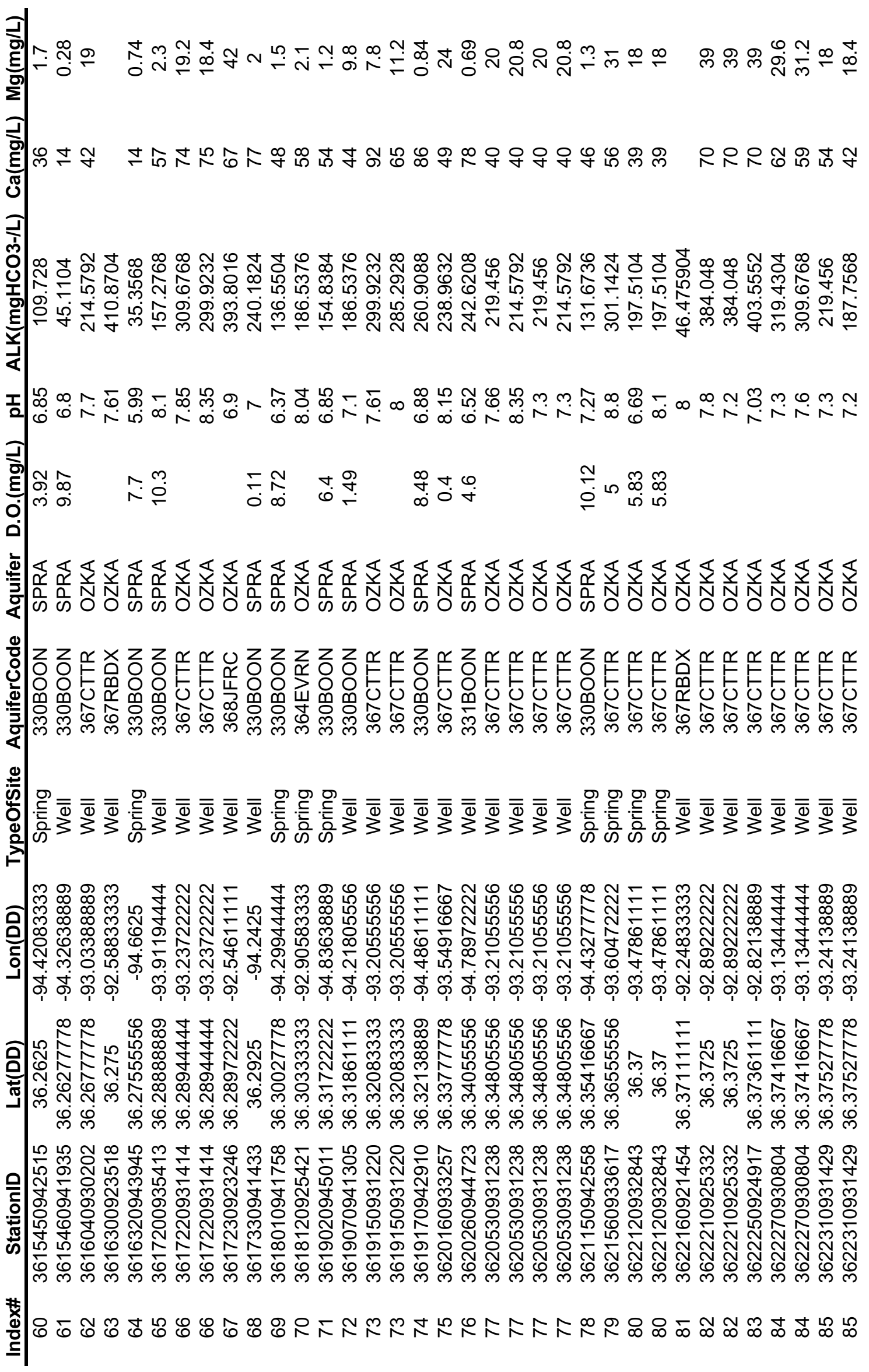




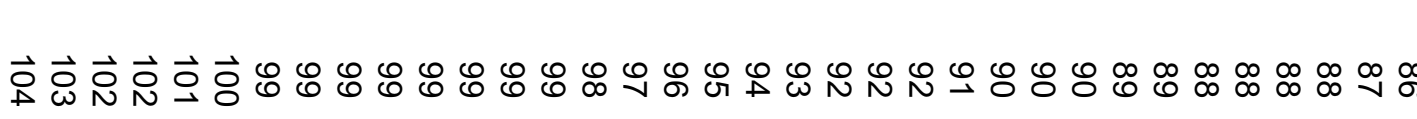

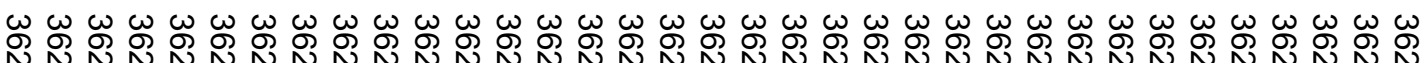
G 虫 N $\omega$ w

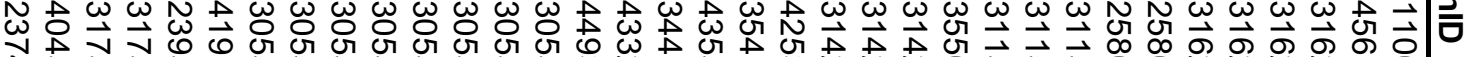

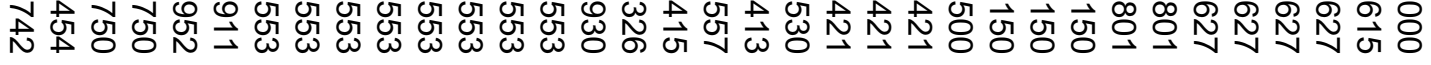

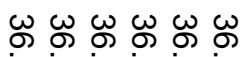

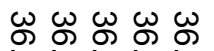

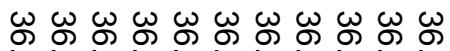

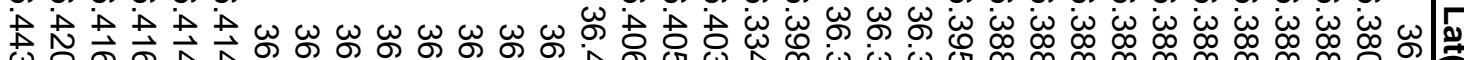
w

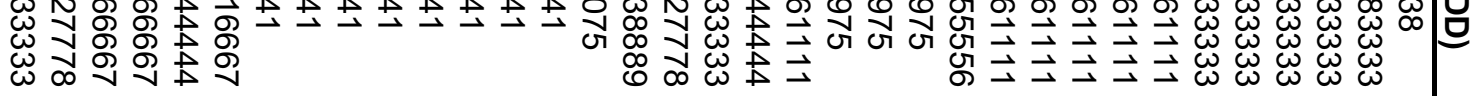

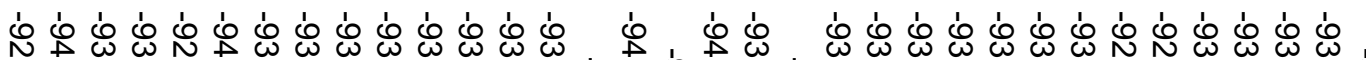
웅 숭 $\infty$ V 㭊 W

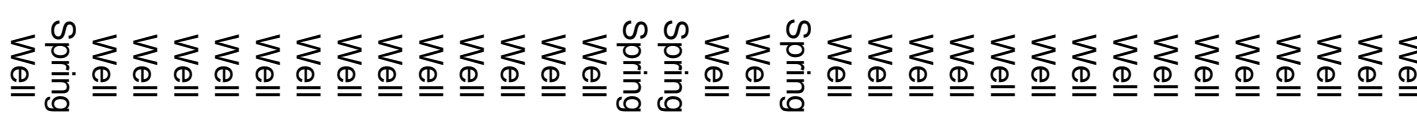
బ 式 있 응 걲

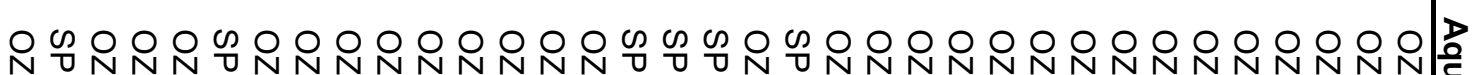

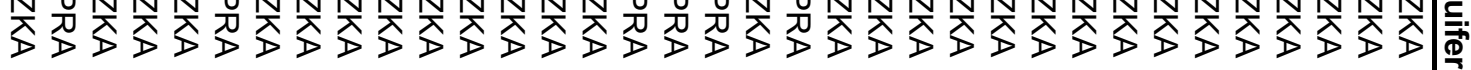

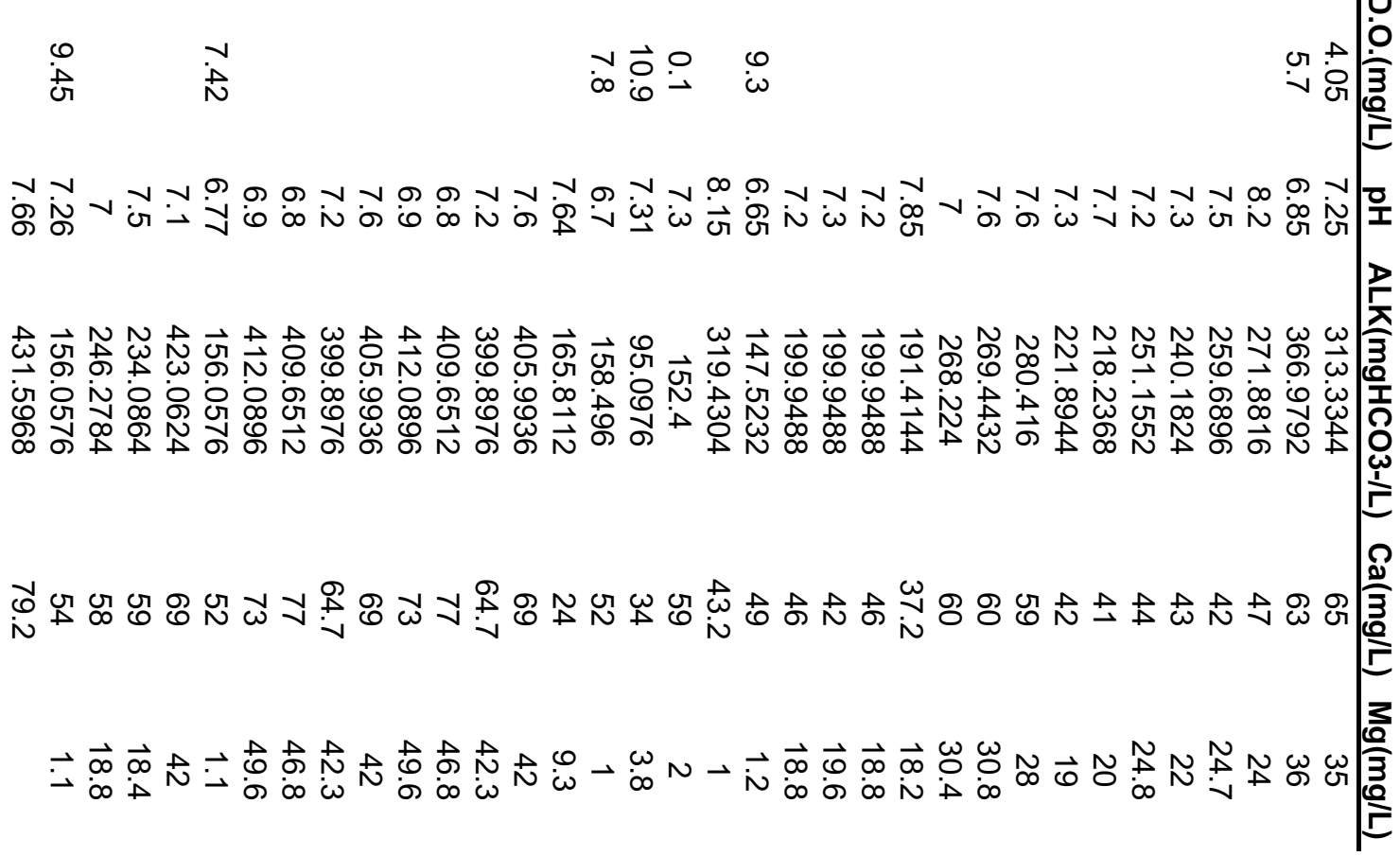




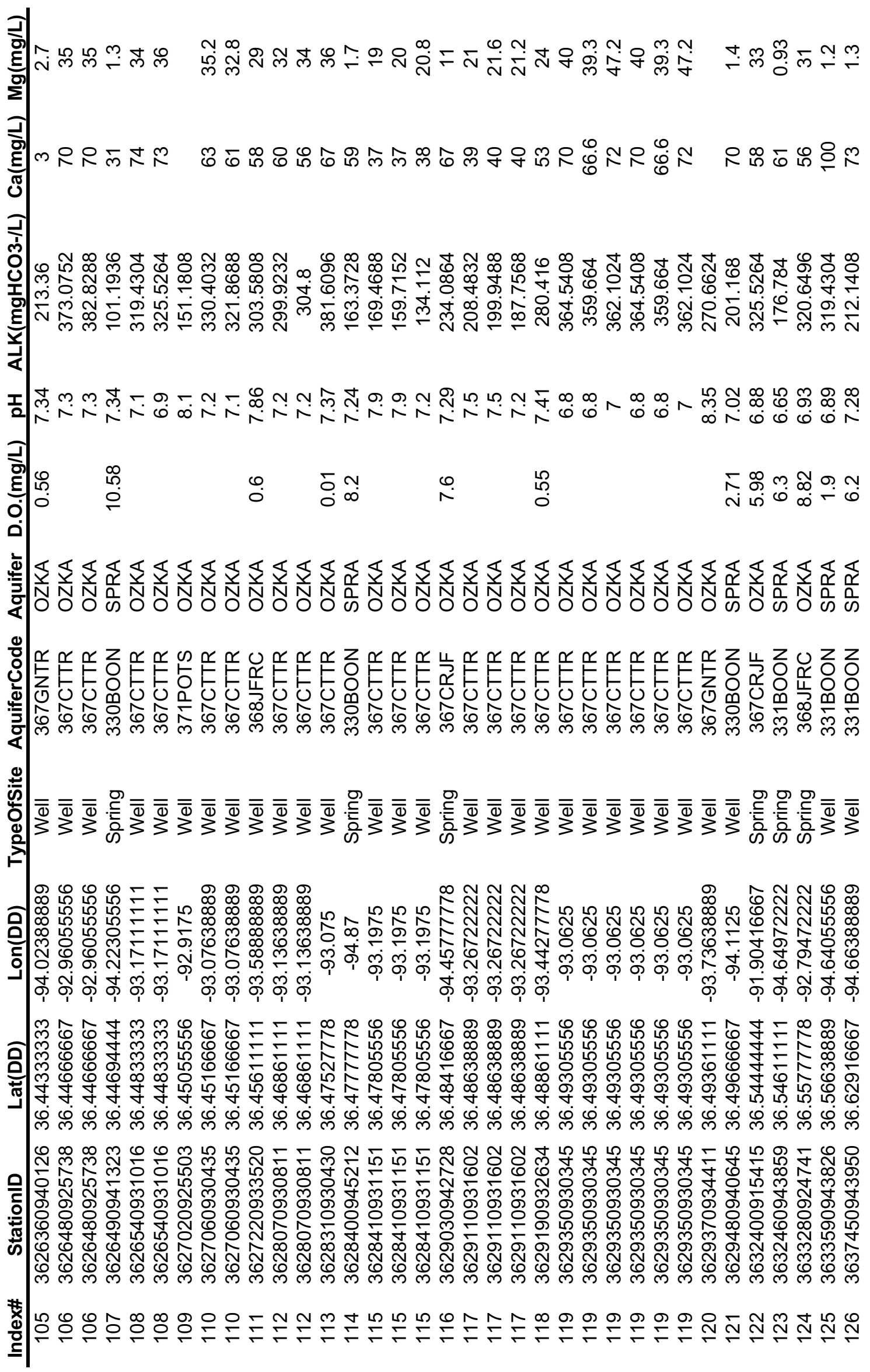




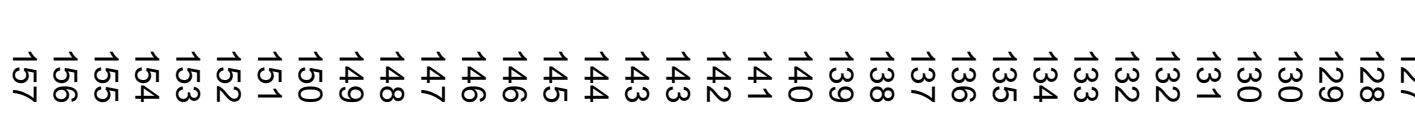

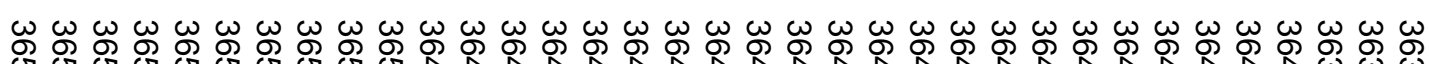

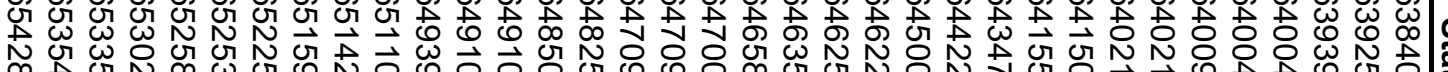

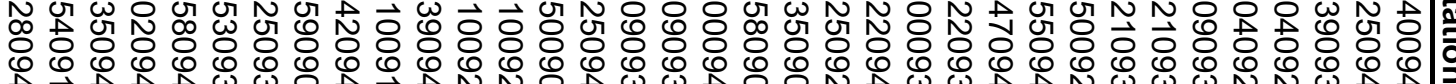

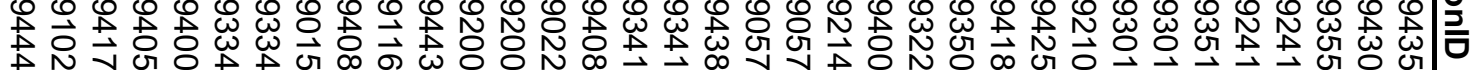

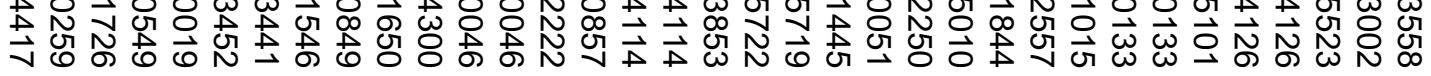

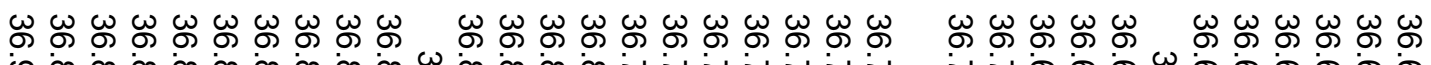
ச0

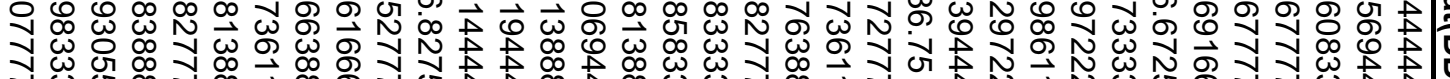

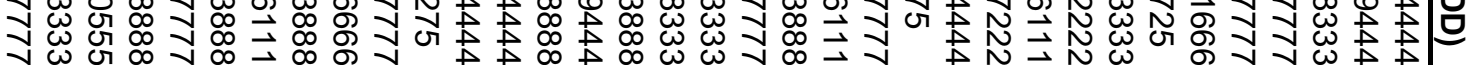

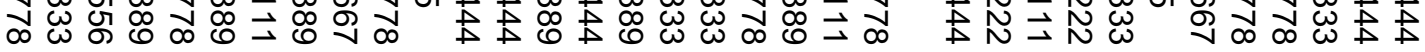

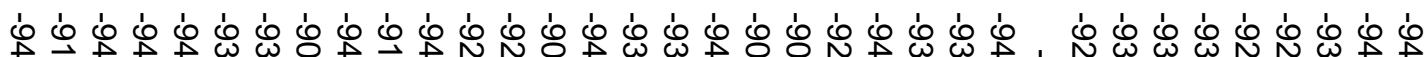
w o 0 o ON N 出 N

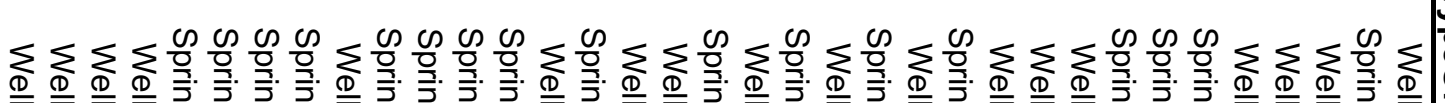

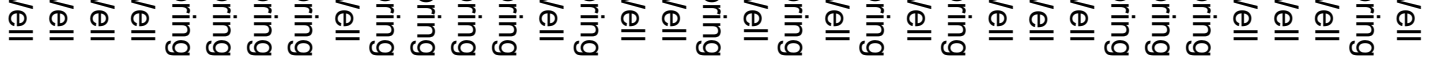

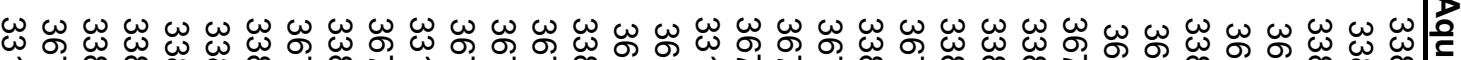

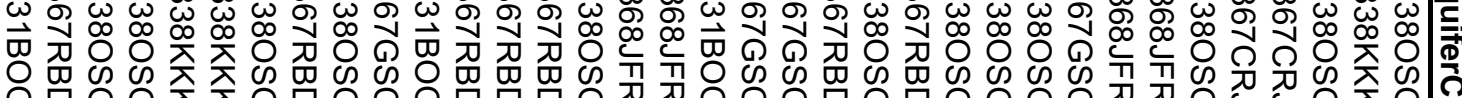

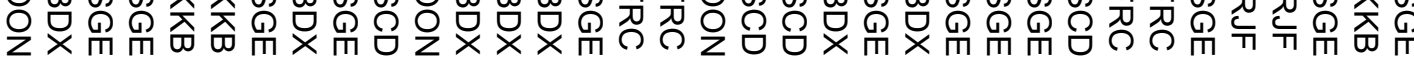

m 은

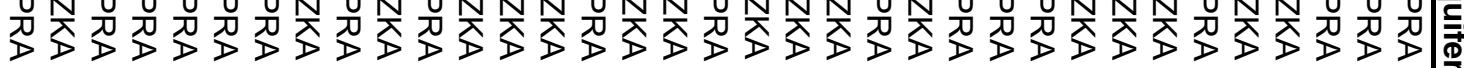

N

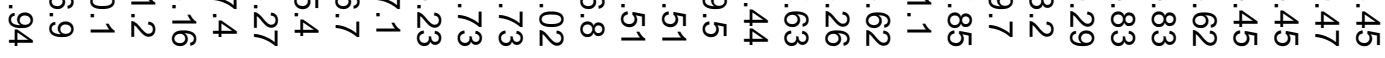
Vงทำ 过立

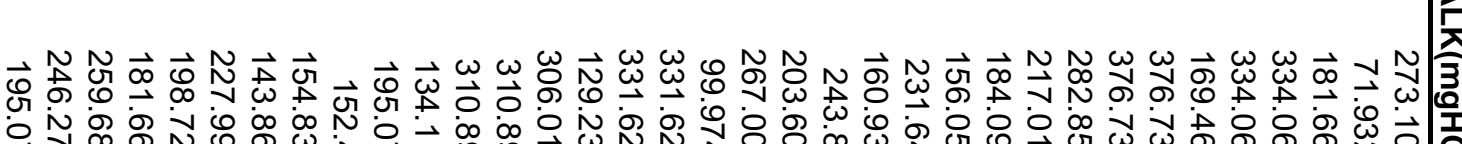

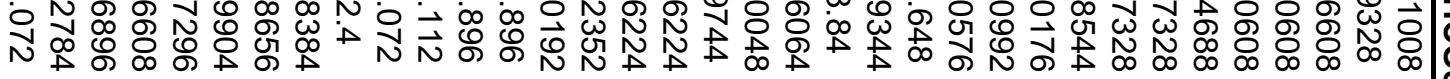

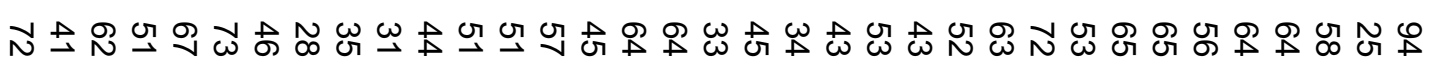

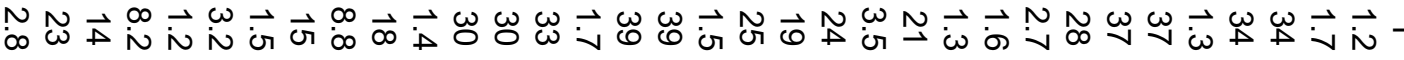




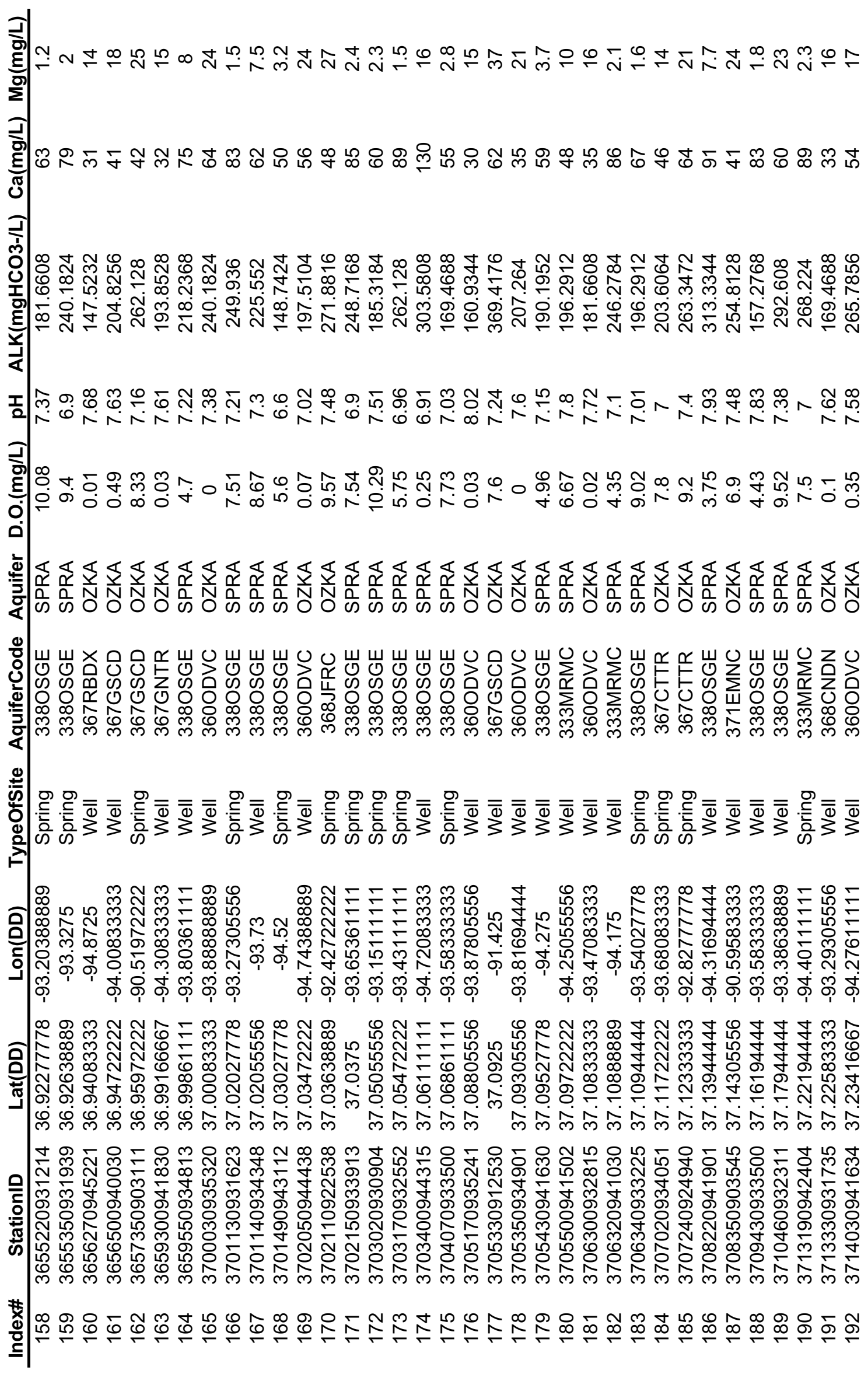




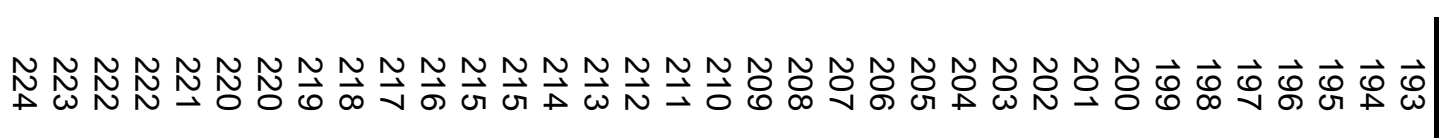

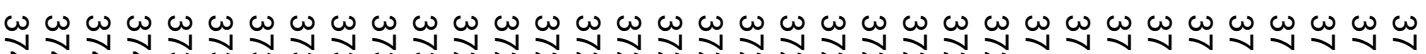

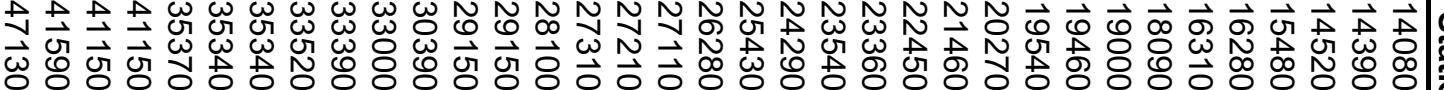

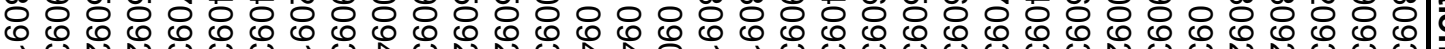

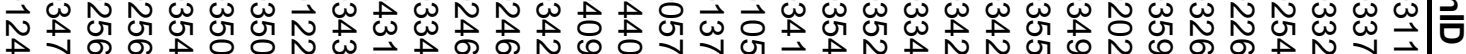

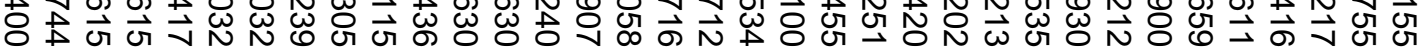

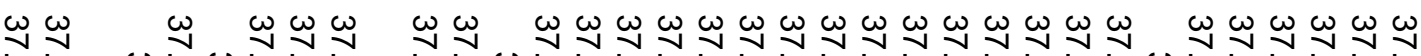

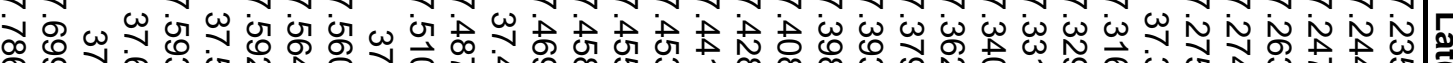
o 0.

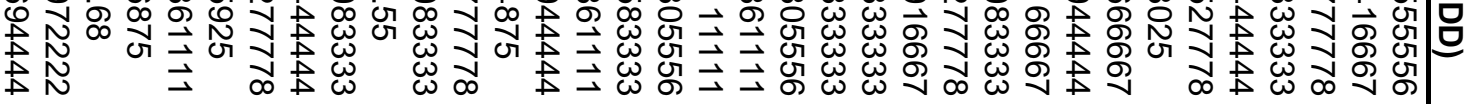

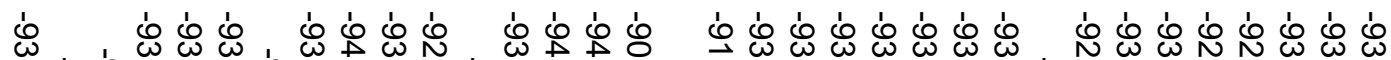
b

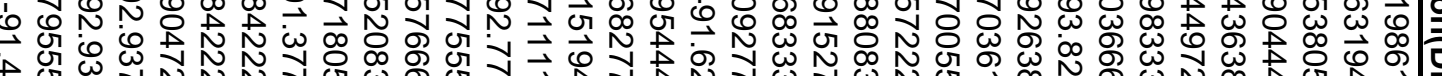

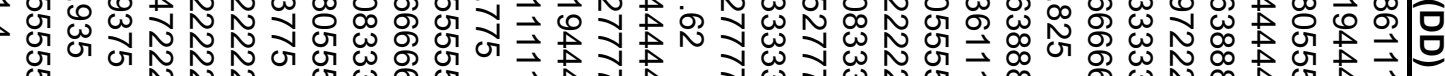

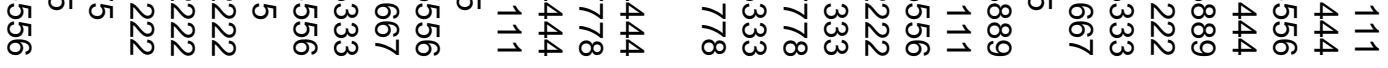

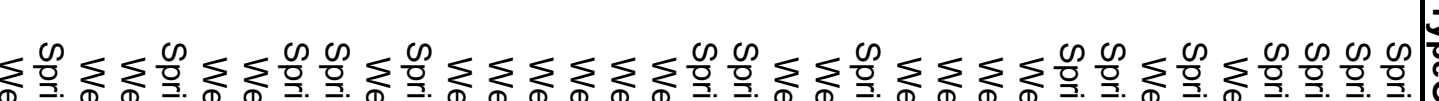

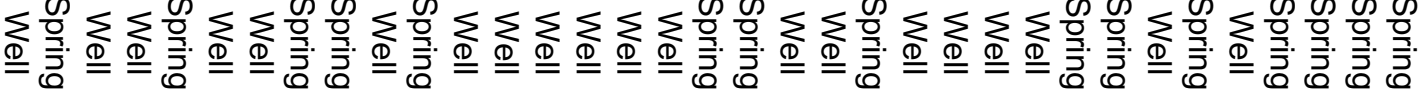

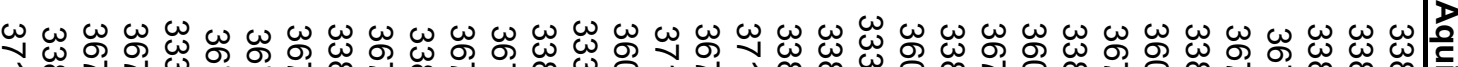

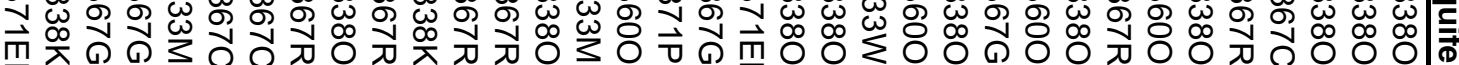

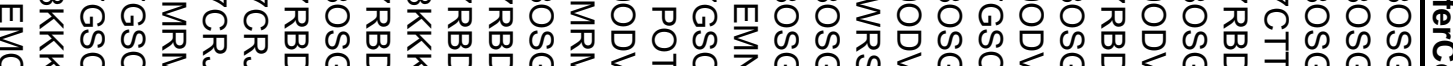

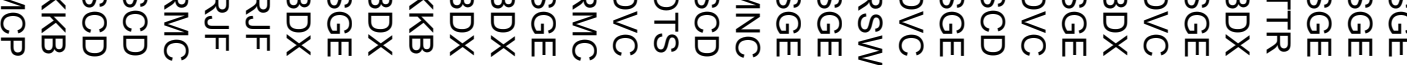

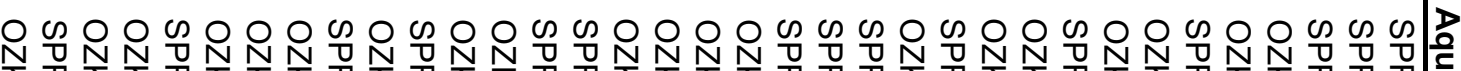

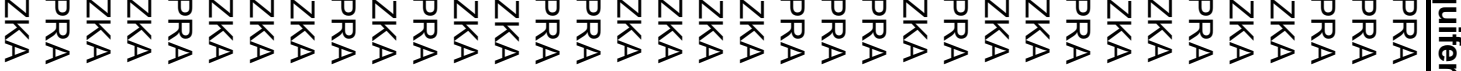

n 崩

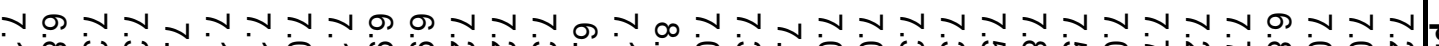

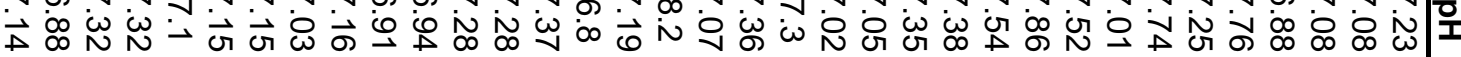

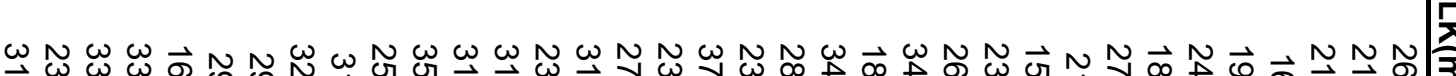

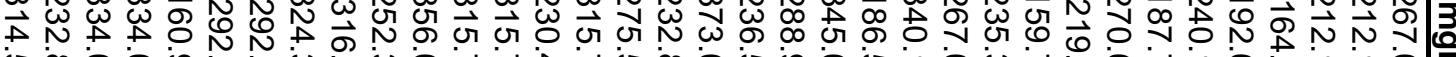

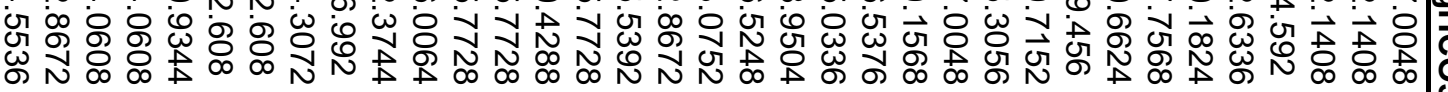

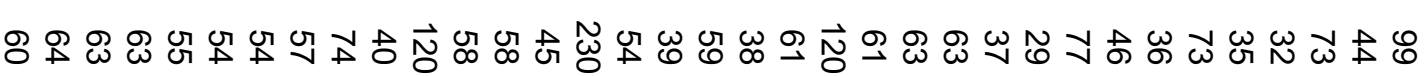

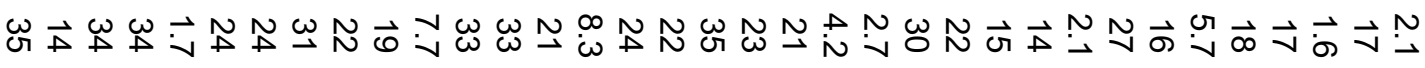




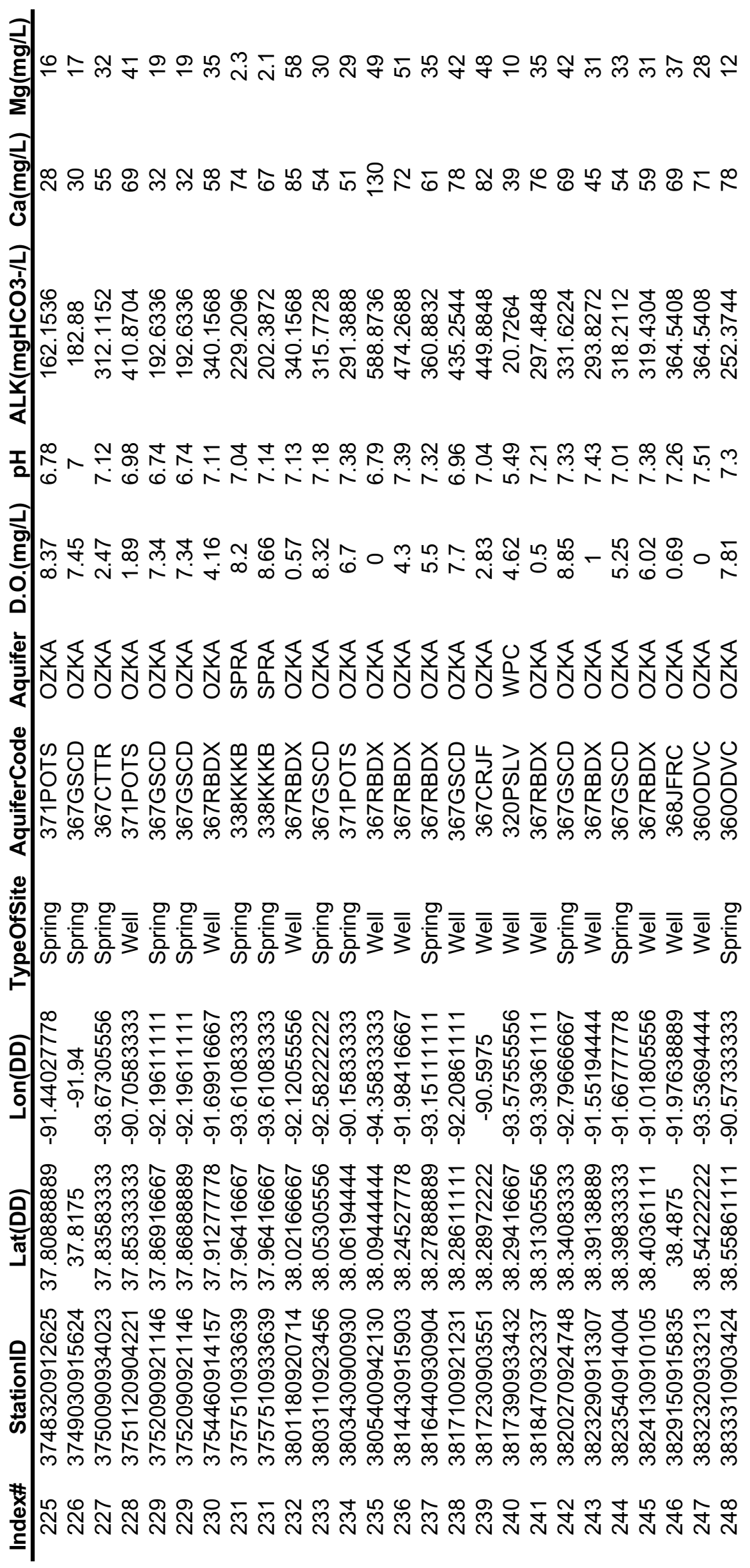




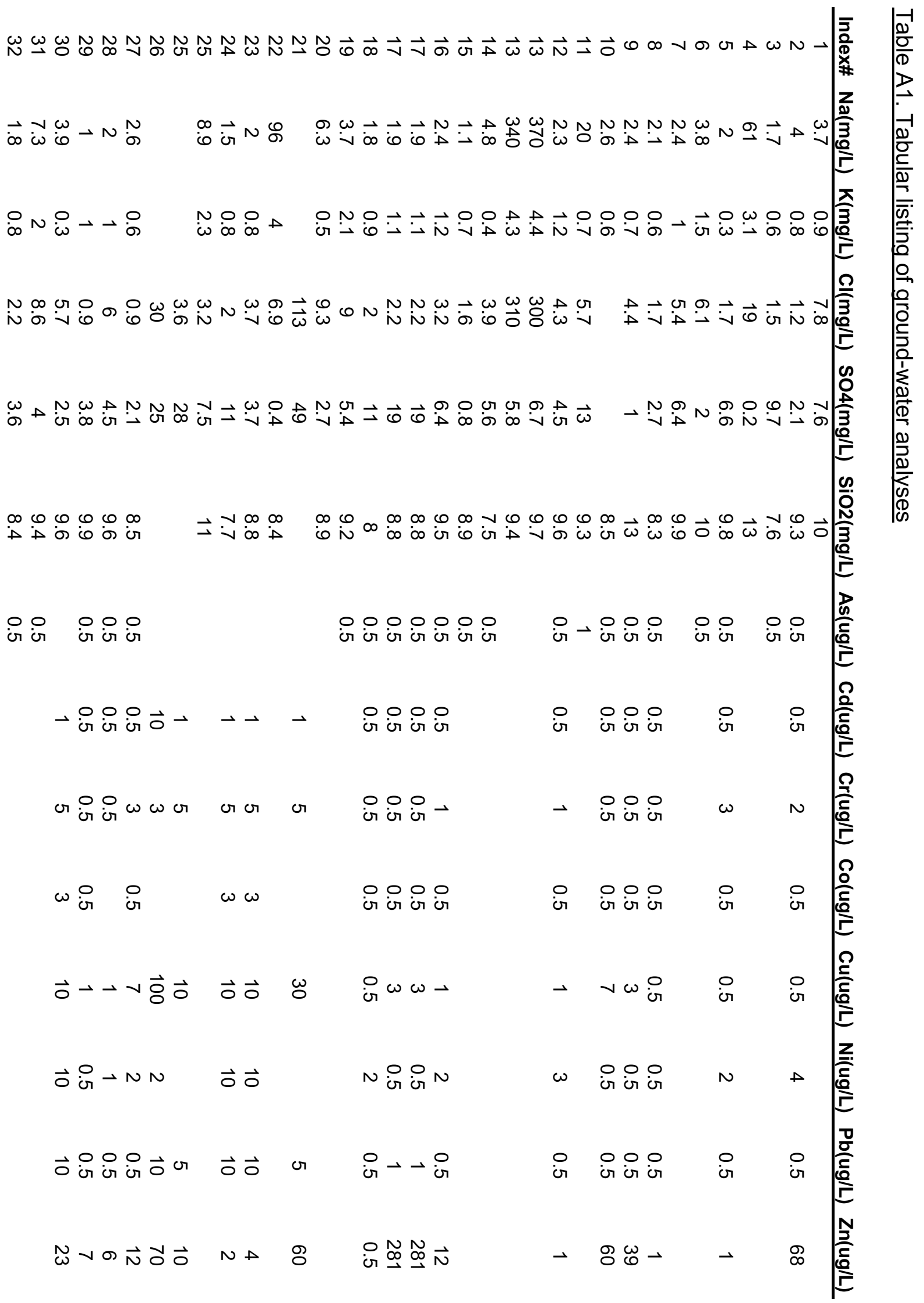




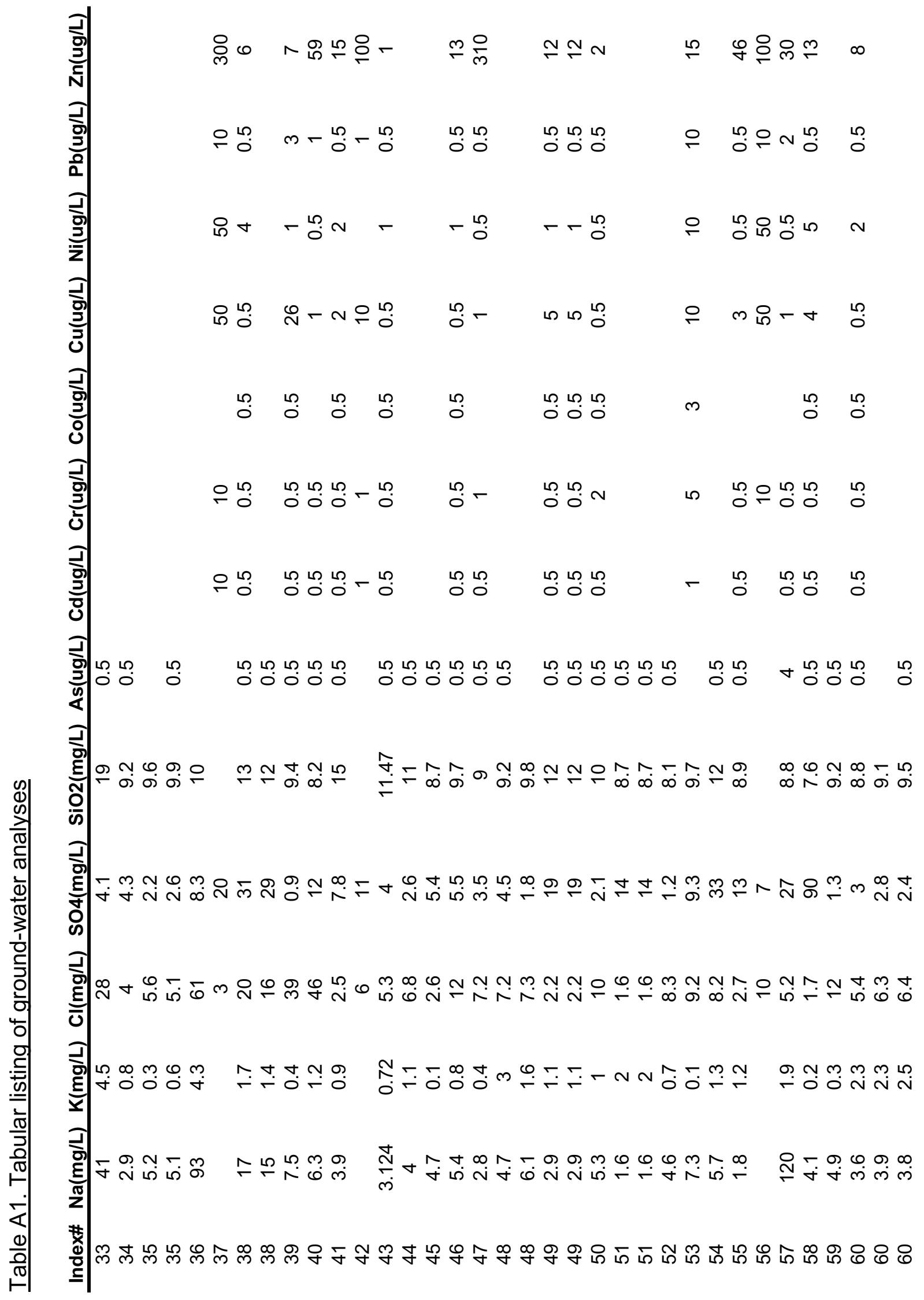




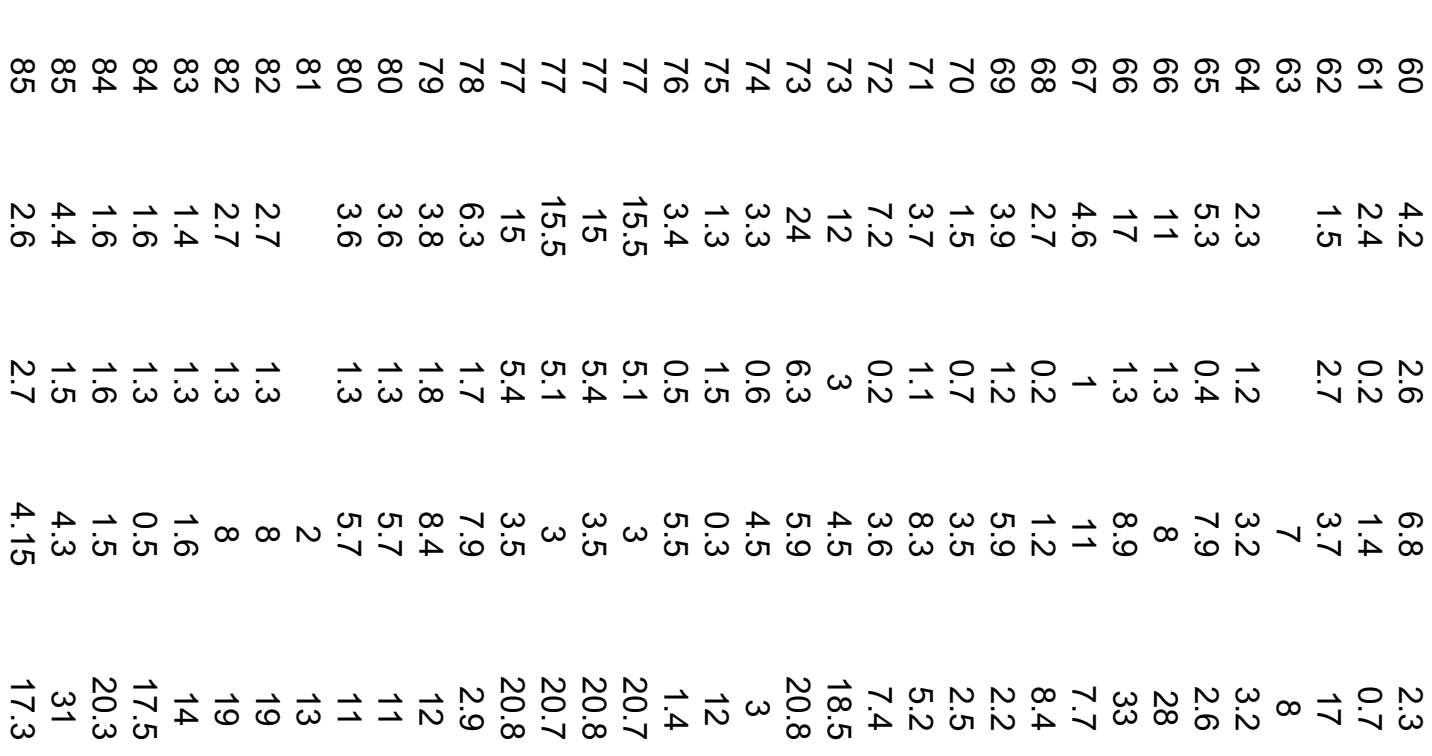

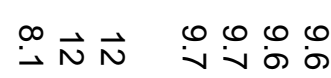

$\stackrel{\infty}{\infty} \infty \infty$

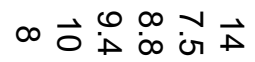

$\vec{\circ} \stackrel{\bullet}{\rightarrow}$

$\infty \stackrel{\omega}{\omega} \dot{\omega}$

앙ํ

앙

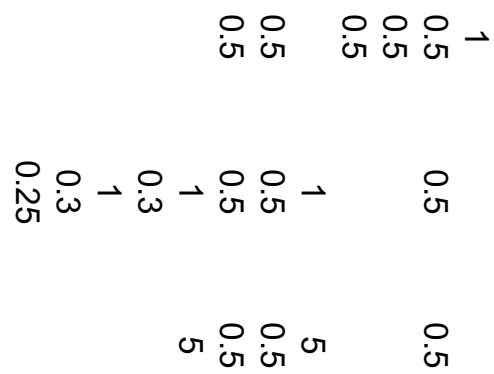

$N N N N \omega$

$-\omega \rightarrow \overrightarrow{\mathrm{i}} \overrightarrow{0} \vee V N$$$
\text { iv }
$$

$N N N N$

$N A$

$\stackrel{N}{\sigma} \omega \stackrel{N}{\sim} \omega \vec{\sigma} N N$

ㅇ 의 $N \stackrel{N}{\sim} \omega$

$\rightarrow \vec{\circ} \vec{\circ} \vec{\circ} \rightarrow-v$

이 $\rightarrow+\rightarrow$

웅

$\rightarrow \vec{\sigma}$

이

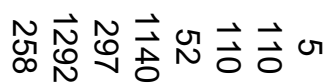

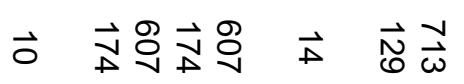

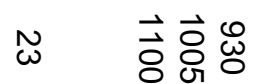

$\omega N N$

$\overrightarrow{0} \rightarrow+$

- 싱

or

$\Delta-\omega$

$\overrightarrow{0}$ 우

N

$-\quad \vec{o}_{\mathrm{\sigma}}^{N} \omega$

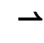

우

$\underset{\infty}{\infty} \underset{0}{\mathbb{\infty}}$ 


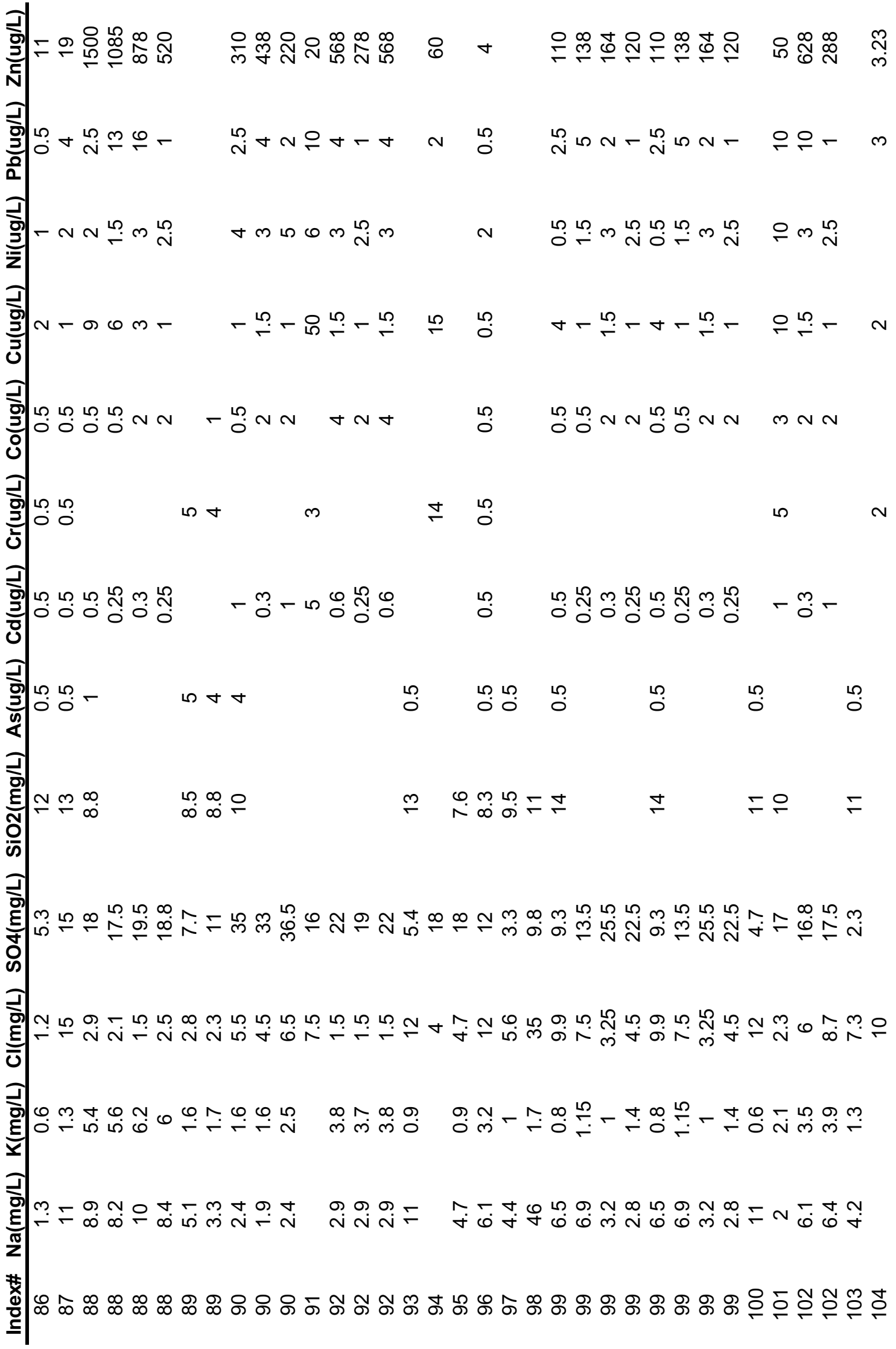




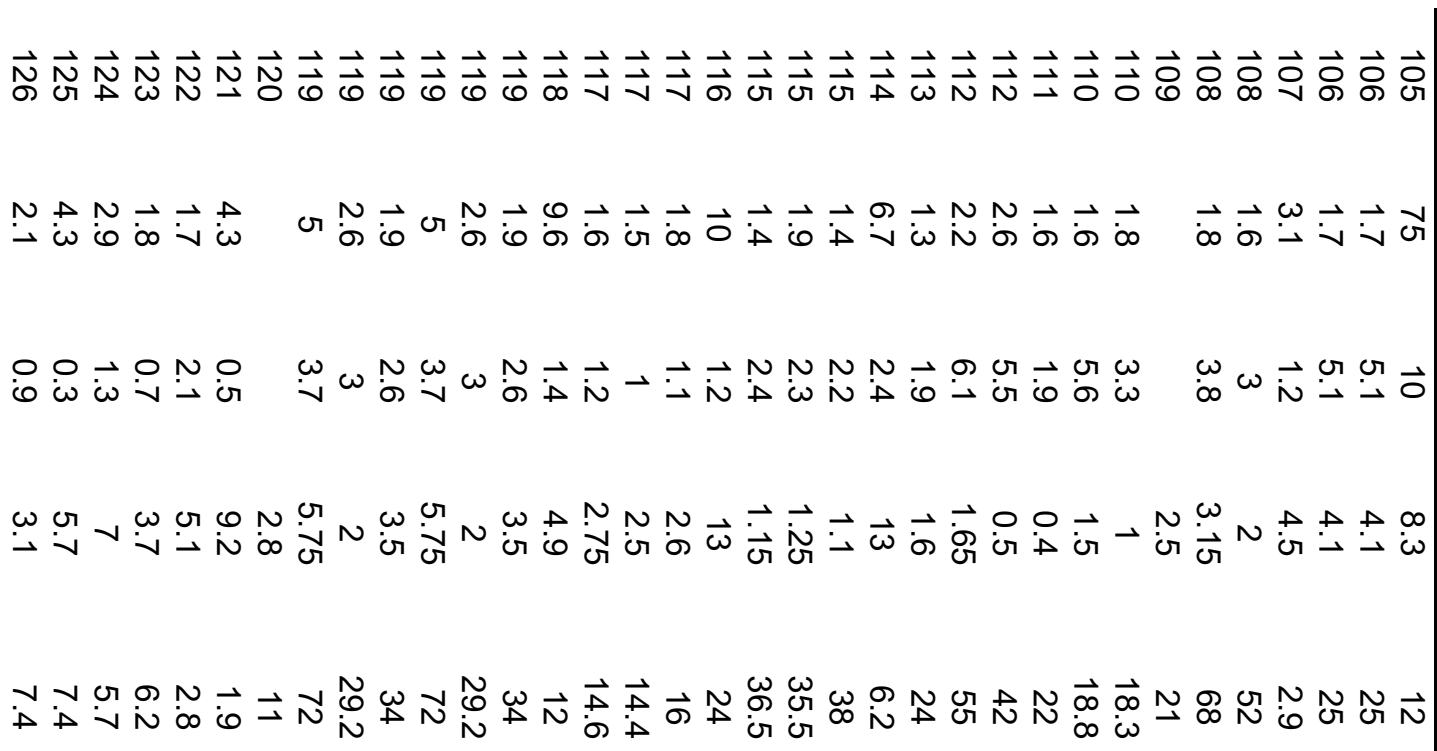

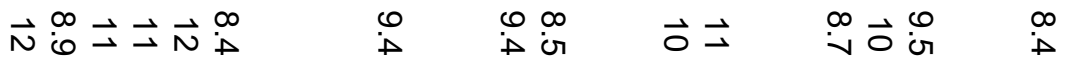

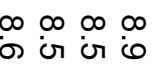

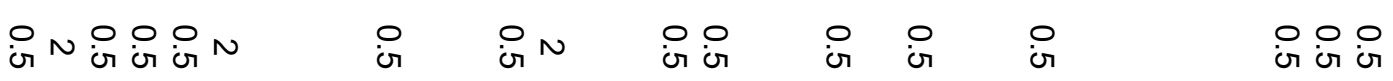

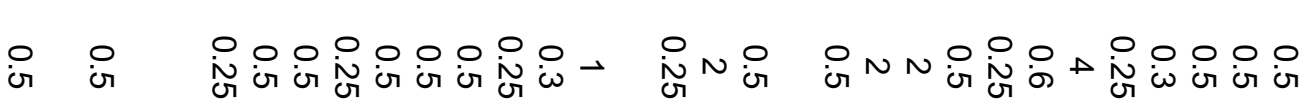

$N$ ir $\overrightarrow{0}$ or or $\circ$ or or $\circ \circ$ or or

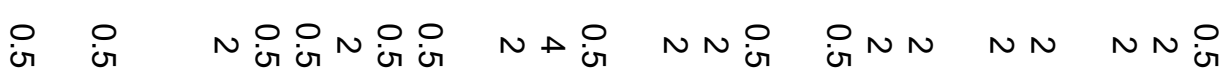

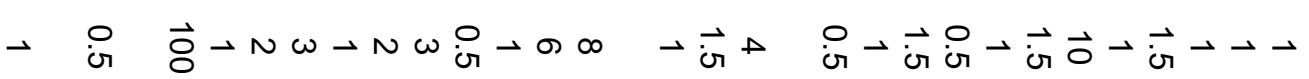

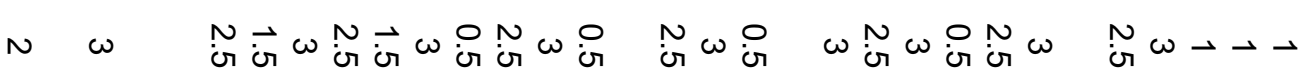

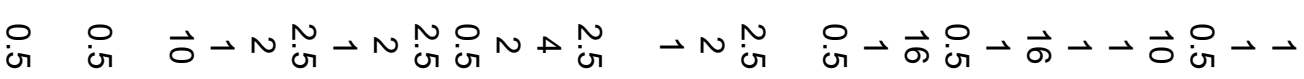

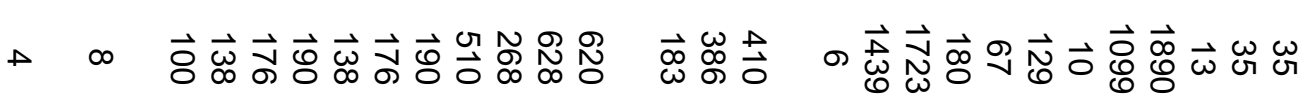




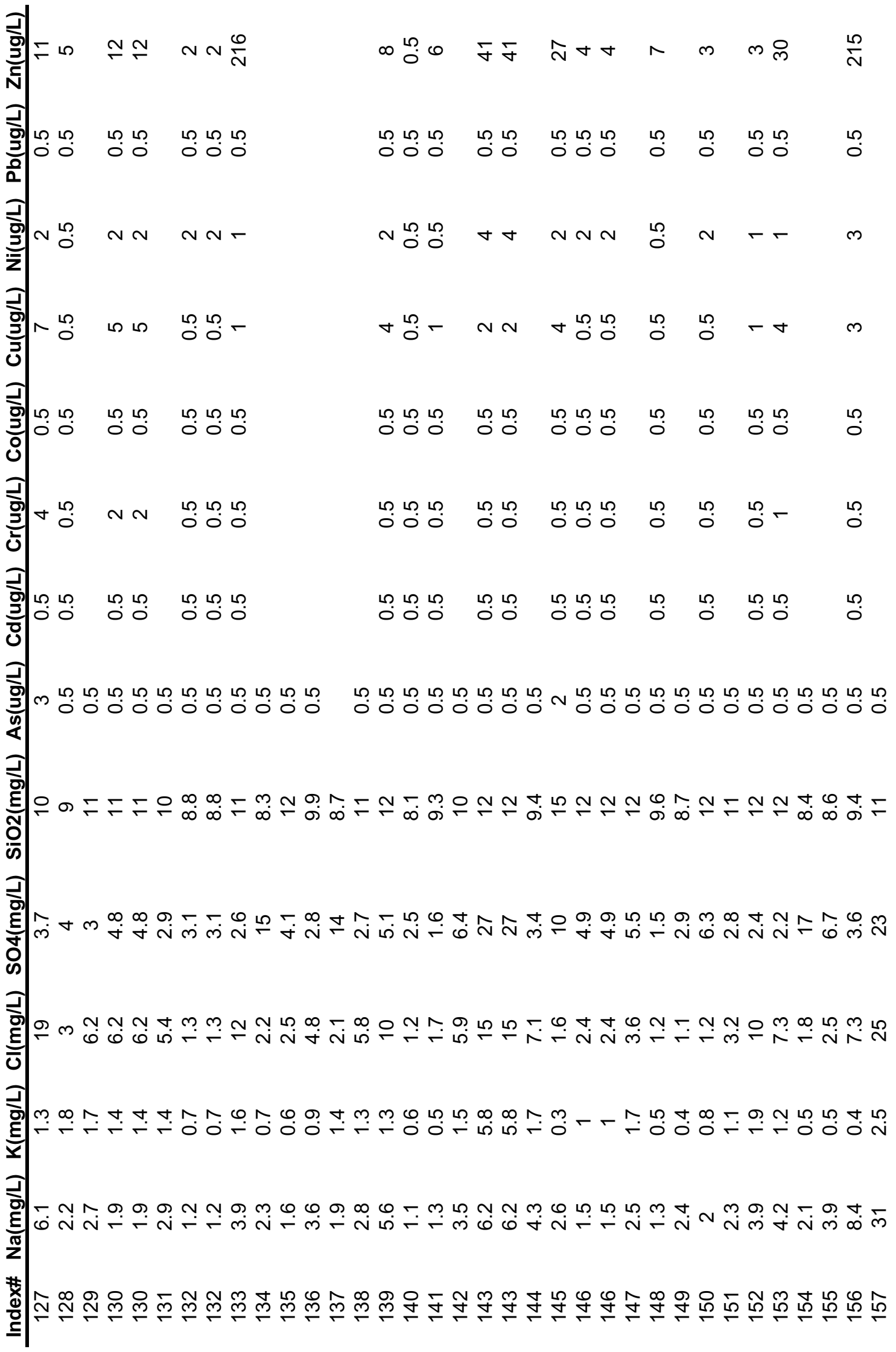




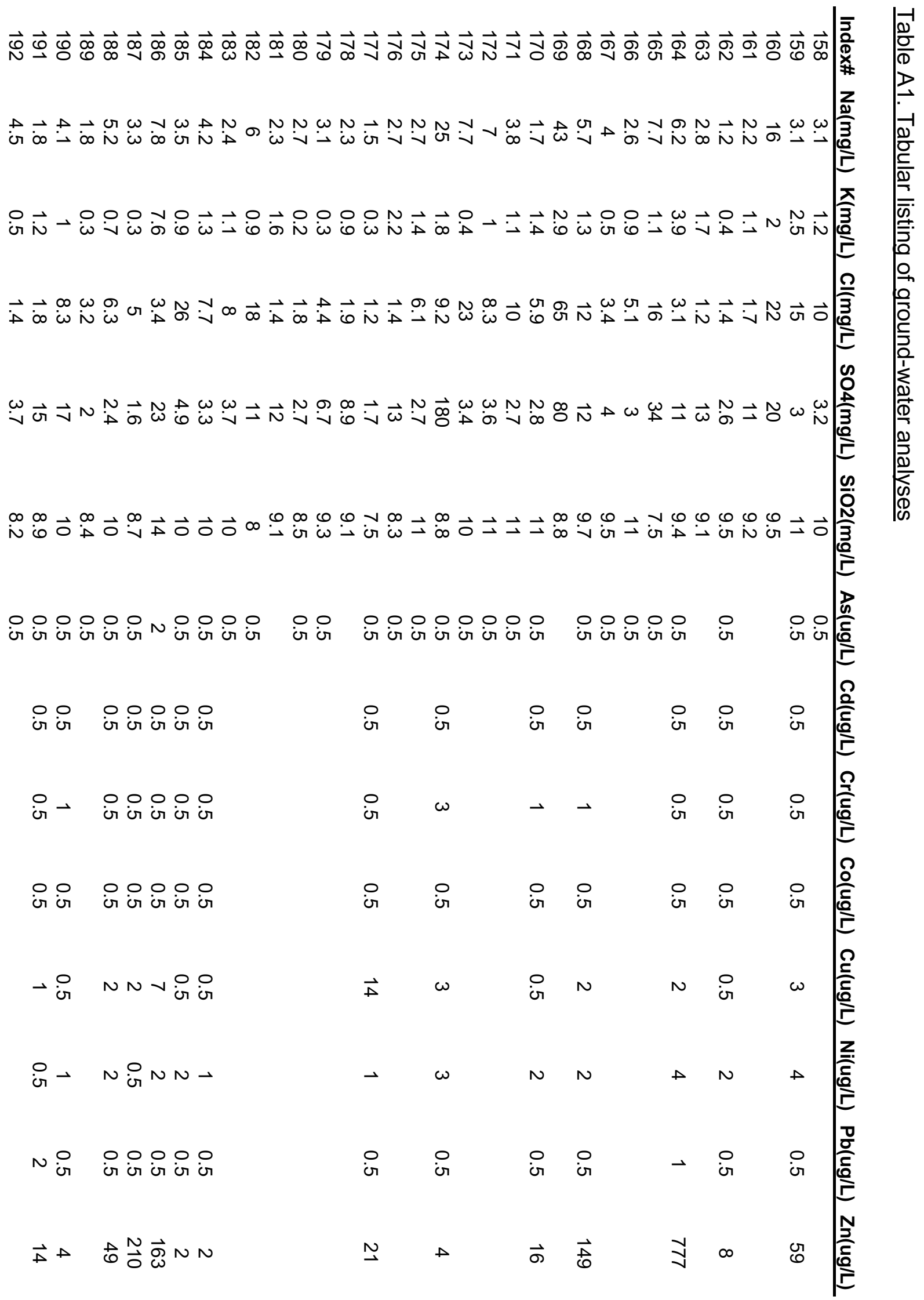




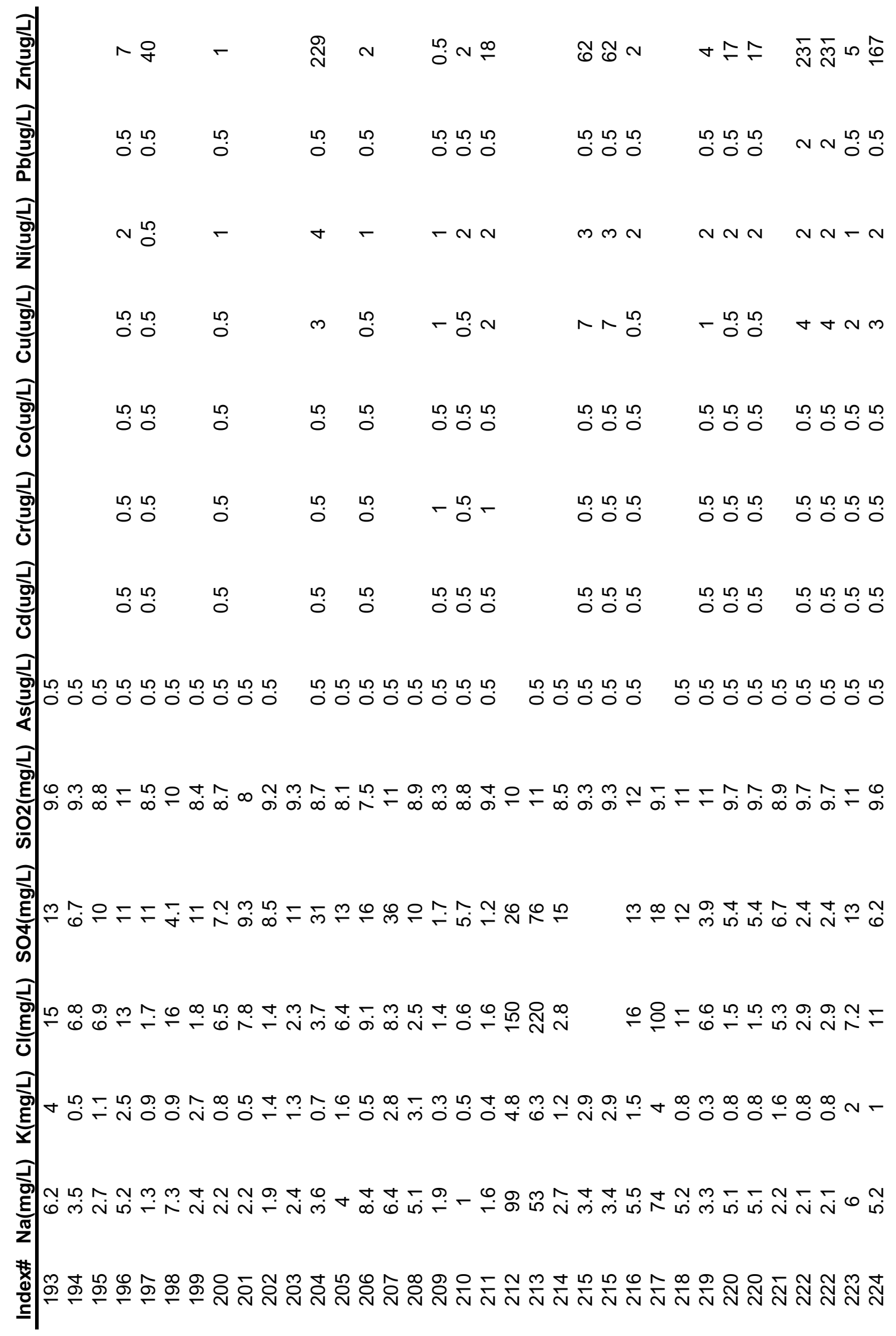




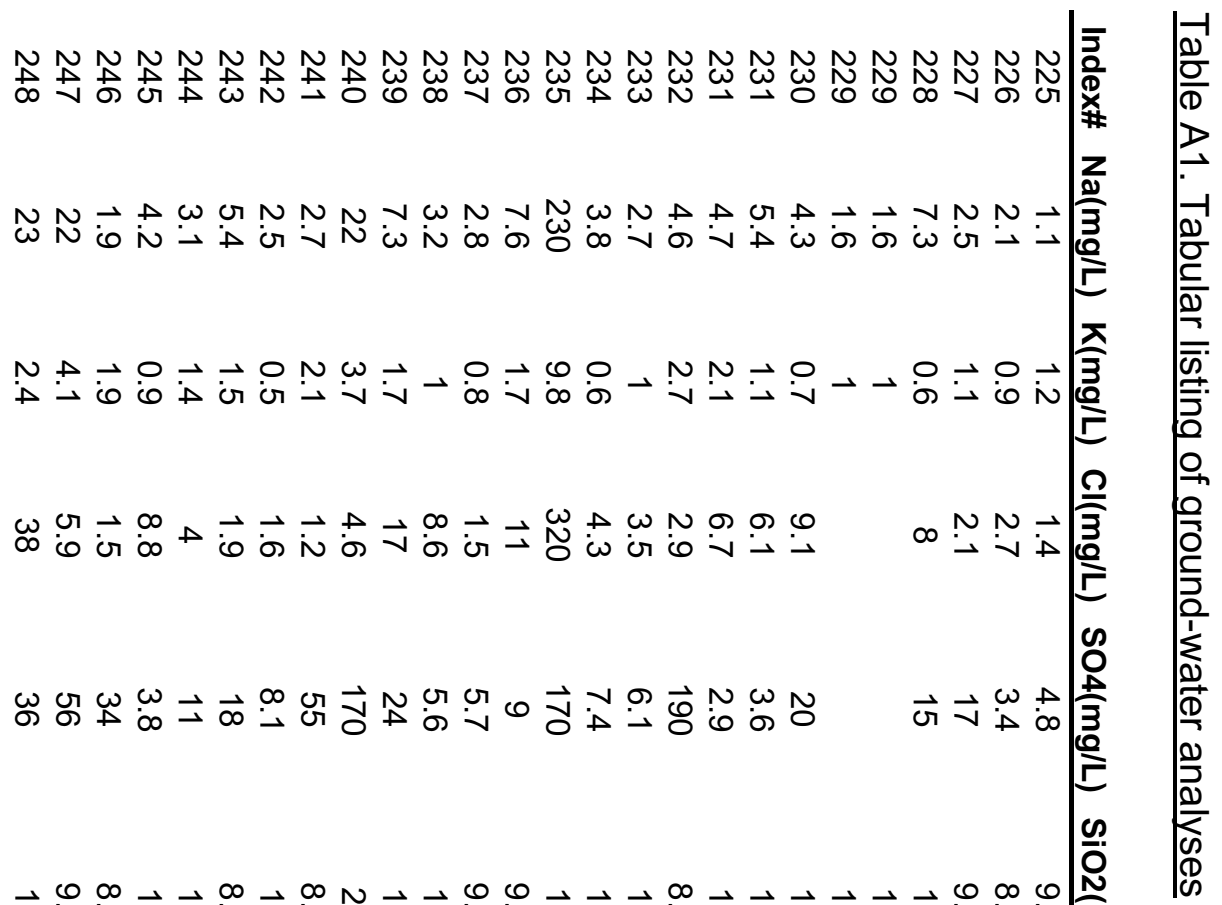

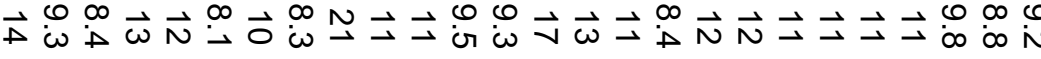

0 0 000 $\rightarrow 000000000000000000$

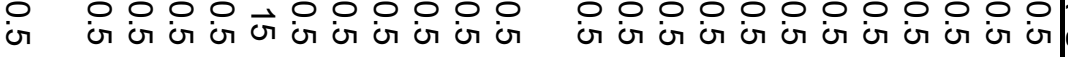

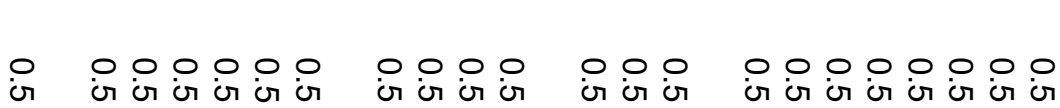

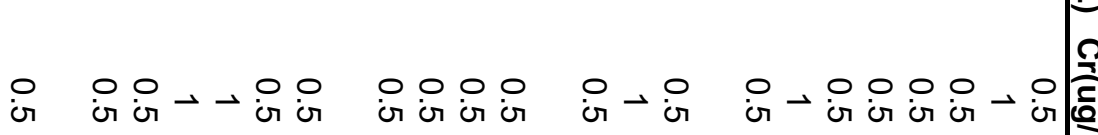
아

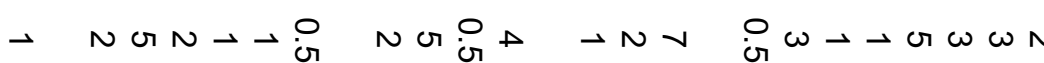
$\omega \rightarrow N-N N N \quad \omega \omega \stackrel{\circ}{\circ} \omega N N \infty N N \rightarrow-\omega N N \rightarrow$

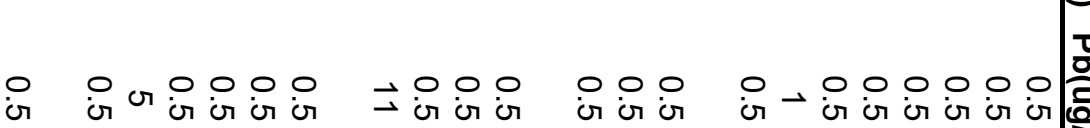

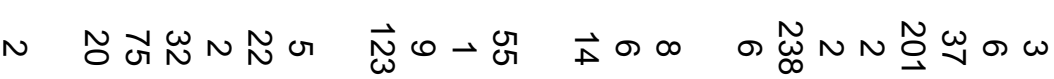

